\title{
ARTICLE
}

\section{IQBAL, TWOMBLY, AND THE EXPECTED COST OF FALSE POSITIVE ERROR}

\author{
Mark Anderson* and Max Huffman**
}

Iqbal and Twombly introduced a new standard for pleading federal claims by overruling five-decades old language from Conley v. Gibson. Instead of plaintiffs being entitled to discovery unless the complaint affirmatively forecloses the possibility of recovery, Iqbal and Twombly require a more searching evaluation of the complaint under an ambiguous "plausibility" standard. The policy behind this increased burden on plaintiffs is to prevent the false positive error that burdensome discovery creates.

How the plausibility standard from Iqbal and Twombly should operate in the real world is poorly understood. There is general acknowledgement that no clear guidance exists about how to ensure only plausible inferences are indulged. Professor Josh Davis recently summed up the sentiments: "Twombly is a very confusing decision. I really do think. . . it's going to be a while before we get a rule that produces predictable results." Professor Adam Steinman is more hyperbolic: "thanks to" Twombly and Iqbal, "federal pleading standards are in a crisis."

This Article fills the void in scholarly and judicial thought by providing an understanding of the Twombly/Iqbal pleading standard that is both theoretically sound and pragmatic. Our approach turns on the policy underlying Iqbal and Twombly-a concern that permitting the case to proceed past the motion to dismiss creates a high-expected cost of false positive error through non-merit-based settlements. The expected cost of false positive error is a function of two variables: the cost to society if the error occurs and the likelihood that the error will occur.

* Professor, University of Idaho College of Law.

** Associate Professor, Indiana University School of Law - Indianapolis. Thanks to Michael Solimine, Florence Roisman, Scott Dodson, Roy Englert, Stuart Ford and Stephen Brown, and the participants in the IU School of Law - Indianapolis fall colloquium series for helpful comments. This work was funded by a summer research grant from the IU School of Law - Indianapolis. Research assistance by Jessica Mitchell, IU School of Law - Indianapolis, Class of 2009, and Jared Joselyn, IU School of Law - Indianapolis, Class of 2010, is also greatly appreciated. Finally, thanks to Sarah Devlin and her colleagues at the Cornell Journal of Law and Public Policy for excellent and patient editorial assistance. 
The cost to society if false positive error occurs varies among different areas of substantive law. The likelihood that false positive error will occur varies by the type of facts in controversy. We use antitrust law as an example of the effects of those two variables. Because false positive error in antitrust is costly to society, the analysis focuses on the likelihood of false positive error.

The likelihood of false positive error depends on the nature of the facts in controversy and the manner in which proof of those facts will be made. If evidence of contested facts is uniquely in the defendant's hands, it can be retrieved (or its absence shown) only through burdensome and asymmetrical discovery by the defendant. If evidence of contested facts is public or quasi-public in nature, it can be gathered without disproportionate burden being placed on the defendant. Whether discovery will be disproportionately burdensome on the defendant will affect the defendant's incentive to settle. Settlements to avoid burdensome discovery result in false positives. Using antitrust law as an example, we demonstrate that different elements of different substantive claims give rise to different likelihoods of false positives. This approach is transsubstantive, and the same inquiry we conduct should be conducted for any claim brought in federal litigation. This analysis resolves the uncertainty left in the wake of Twombly and Iqbal.

InTRODUCTION........................................ 3

I. Development of the Plausibility Standard .......... 5

A. Leatherman and Dura Pharmaceuticals............ 6

1. Plain-Language Interpretation of the Federal

Rules .............................. 7

2. Pleading Elements $\ldots \ldots \ldots \ldots \ldots \ldots \ldots \ldots . \ldots$

B. Twombly.............................. 9

C. Iqbal ................................ 12

1. The Story of Iqbal ................... 13

2. Iqbal's Analysis of Twombly............... 14

3. A Dissenting View ..................... 15

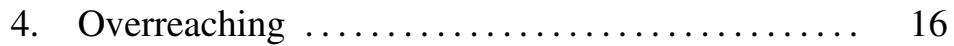

D. Unifying Rationales ...................... 18

II. Applying the TwOMbly/IQbal Framework to

Different Types of Facts ...................... 20

A. False Positive Error Can Result from Denying a Motion to Dismiss ..............................

B. False Positive Error is Costly in Antitrust and Civil Rights Claims .............................

C. Determining the Expected Cost of False Positive Errors .................................... 
D. The Likelihood of False Positive Error is Greater if Discovery Will Be Especially Burdensome ...........

E. The Plausibility Standard Turns on the Expected Cost of False Positive Error ......................

III. Applying the Twombly/IQbal Framework to

Antitrust Claims .............................. 29

A. Conspiracies Restraining Trade .............. 30

1. Agreement .......................... 30

2. Reasonableness ..................... 35

B. Monopolization ..................... 38

1. Market Power............................ 39

2. Conduct ....................... 41

a. Predatory Pricing $\ldots \ldots \ldots \ldots \ldots \ldots . \ldots \ldots$

b. Unilateral Refusals to Deal ............ 45

c. Monopoly Leveraging .............. 48

IV. Testing CAses......................... 51

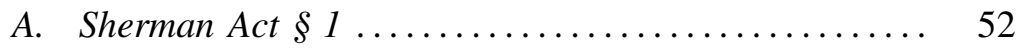

1. Agreement...................... 52

a. Circumstantial Allegations ........... 52

b. Direct Allegations .................. 57

2. Reasonableness ...................... 60

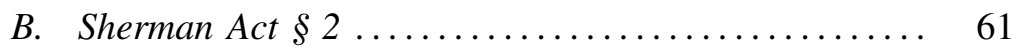

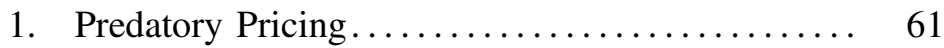

2. Monopoly Leveraging ............... 62

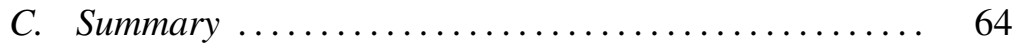

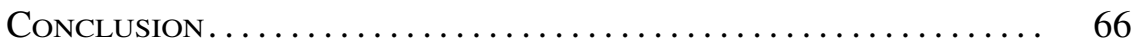

\section{INTRODUCTION}

In Ashcroft v. Iqbal, ${ }^{1}$ the plaintiff alleged that then-Attorney General John Ashcroft and FBI Director Robert Mueller violated his civil rights by incarcerating him under harsh conditions in the wake of the September 11, 2001 terrorist attacks on account of his race, religion, or national origin. The plaintiff's complaint failed to state a claim under Rule 8 and, the Supreme Court held, was subject to dismissal. ${ }^{2}$ In Bell Atlantic Corp. v. Twombly, ${ }^{3}$ the plaintiffs alleged that defendant local telephone carriers had failed to enter into competition with one another in their respective monopoly service markets, despite the plaintiffs' expectation that competition would occur after local telephone service was deregulated in 1996. On information and belief, the defendants had con-

\footnotetext{
1129 S. Ct. 1937 (2009)

$2 \mathrm{Id}$. at 1954.

3550 U.S. 544 (2007).
} 
spired, but again, the Supreme Court approved the district court's dismissing the complaint because it failed to state a claim. ${ }^{4}$

Iqbal made clear for the first time that Twombly's controversial pleading standard applied to all civil actions under the Federal Rules, and not only to the antitrust conspiracies directly at issue in Twombly. The pleading standard set forth in Rule 8, and enforced by dismissals under Rule 12(b)(6), controls when a plaintiff will have access to discoveryand potentially trial-in federal court in all civil claims. Twombly and Iqbal set forth a murky standard phrased in terms of the "plausibility" of the inferences to be drawn from the factual allegations in the complaint. Because the plausibility standard controls access to litigation in every civil action in federal court, piercing the murk of the Twombly/Iqbal plausibility standard is crucial. This Article analyzes the underlying rationale for the Twombly/Iqbal standard and argues that the trans-substantive rule applies differently to various types of factual allegations. The height of the plausibility standard thus varies depending on the nature of the facts relevant to the substantive element pled.

The Twombly/Iqbal plausibility standard is rooted in a concern that allowing a plaintiff to proceed to discovery creates a possibility that a defendant facing a nonmeritorious claim will settle rather than endure the burdens of discovery. Such settlements create so-called "false positives," because a plaintiff recovers a remedy to which she is not entitled. False positives reflect a wealth transfer from an innocent defendant to an undeserving plaintiff. They also induce parties to order their affairs to avoid innocent behavior that might give rise to false positives in the future. This over-deterrent effect results in harm to parties who never end up in court, and imposes an external social cost where the over-deterred party's conduct is beneficial. The relevant question is not absolute cost, but the expected cost of false positive error.

The expected cost of false positives also depends on the likelihood of false positives. The likelihood of false positives turns on the burden created by discovery in a particular context. Nonburdensome discovery does not produce a great incentive to settle. ${ }^{5}$ Burdensomeness depends on the nature of the contested facts. Facts that are uniquely in the hands of the defendants threaten to create a substantial burden. Contested facts available both to the plaintiff and the defendant threaten a much lesser burden. Whether facts are uniquely in the hands of the defendant varies

4 Id. at 548.

5 Of course, a defendant concerned about the result in litigation is incentivized to settle no matter how light the discovery burden, but such a settlement does not reflect a false positive connected to an unduly permissive pleading standard. But see Daniel Crane, Technocracy and Antitrust, 86 Tex. L. REv. 1159, 1185 (2008) (explaining Twombly by reference to fears of jury incompetence). 
depending on the particular element of a substantive claim in controversy.

Part I analyzes the change in the pleading standard that occurred in Twombly and Iqbal. Part II examines the rationale for the Twombly/Iqbal plausibility standard and its relationship to the various types of facts that can be put in controversy by different types of elements of substantive claims. This examination produces the conclusion that applying the Twombly/Iqbal standard requires separately analyzing the likelihood of false positives raised by each element of a substantive claim. Part III undertakes this analysis in the context of antitrust claims under Sections One and Two of the Sherman Act. The sub-parts of Part III identify an element of a Sherman Act claim, analyze the nature of facts necessary to prove the element, and explain how the plausibility standard should apply to facts of that nature. In Part IV, we test decided cases for their adherence to the expected cost of false positive error framework. We conclude in the final Part by suggesting that a similar element-by-element analysis is necessary for each substantive field of federal civil litigation.

\section{Development of the Plausibility Standard}

Prior to 2007, with Conley v. Gibson ${ }^{6}$ as the leading authority on federal pleading standards, most believed plaintiffs were entitled to litigate beyond the complaint so long as the complaint itself did not affirmatively foreclose the plaintiff's right to relief. ${ }^{7}$ That doctrine is no longer valid. ${ }^{8}$

Twombly involved a cartel-conduct claim. Allegations of conduct culminating in an allegation that "on information and belief, the defendants conspired" did not sufficiently make out a conspiracy claim capable of surviving the defendant's motion to dismiss. ${ }^{9}$ The Twombly Court "re-

6355 U.S. 41 (1957).

7 One of us has argued that this understanding of Conley is shortsighted and was never followed by courts. See Max Huffman, The Necessity of Pleading Elements in Private Antitrust Conspiracy Claims, 10 U. PA. J. Bus. \& EMP. L. 627, 636 (2008) [hereinafter Huffman, The Necessity of Pleading Elements in Private Antitrust Conspiracy Claims]. Statistical data offers grounds to question how meaningful Twombly has actually been on the dismissal rates in federal litigation. A snapshot of that data suggests dismissal rates have decreased. Compare U.S. District Courts-Civil Cases Terminated, by Nature of Suit and Action Taken, U.S. Courts (June 30, 2008), available at http://www.uscourts.gov/Statistics/FederalJudicial CaseloadStatistics.aspx (reporting that in the twelve months prior to June 30, 2008, 151,841 of 177,926 cases (85\%) with court action were resolved "before pretrial"), with U.S. District Courts-Civil Cases Terminated, by Nature of Suit and Action Taken, U.S. CourTs (June 30, 2005), available at http://www.uscourts.gov/Statistics/FederalJudicialCaseloadStatistics.aspx (reporting that in the 12 months prior to June $30,2005,192,252$ of 217,171 cases (88\%) with court action were resolved "before pretrial").

8 See Twombly, 550 U.S. at 562-63.

9 See id. at $548-49$. 
tire[d]" the "any state of facts" standard from Conley v. Gibson ${ }^{10}$ for evaluating complaints. ${ }^{11}$

Iqbal arose two years later in the entirely different context of a Bivens ${ }^{12}$ action against the nation's top law enforcement officials, then-Attorney General John Ashcroft and FBI Director Robert Mueller. The plaintiff, a Pakistani Muslim man, alleged that the defendants had discriminated against him, in violation of his rights under the U.S. Constitution. ${ }^{13}$ The complaint alleged that the defendants had "adopted an unconstitutional policy that subjected [the plaintiff] to harsh conditions of confinement on account of his race, religion, or national origin." 14 Iqbal is a more dramatic departure from the previously-settled understanding of the law governing pleading in federal court cases. At a minimum, Iqbal demonstrates that courts holding Twombly applicable outside its narrow context have been correct. ${ }^{15}$ Iqbal also informs the application of the Rule 8 standard in antitrust cases. The remainder of this Part details the development of the Rule 8 pleading standard over the past two decades in the Supreme Court.

\section{A. Leatherman and Dura Pharmaceuticals}

Pleading authorities growing out of Conley v. Gibson-primarily Leatherman v. Tarrant County Narcotics Intelligence \& Coordination Unit $^{16}$ and Dura Pharmaceuticals, Inc. v. Broudo ${ }^{17}$ —detail courts' reviews of allegations by private plaintiffs in various circumstances. Leatherman teaches that heightened pleading under Federal Rule of Civil Procedure 9(b) is not available for claims-in that case, federal civil

10355 U.S. 41 (1957).

11 Twombly, 550 U.S. at 562-63. Twombly set off shock waves jarring antitrust and civil procedure scholars alike. See Kevin Clermont, Litigation Realities Redux, 84 N.D. L. Rev. 1919, 1934 n.74 (2009) (citing multiple articles). The reaction to Twombly in the courts is more difficult to gauge. Twombly has been widely cited and discussed. See id. at n.73. Although thousands of courts have cited and discussed Twombly, relatively few have spilled much ink on careful analyses of the purported new pleading standard and its impact on their decisions on motions to dismiss. Twombly's enormous citation counts are misleading. Pleading cases, not surprisingly, attract substantial citations for their legal propositions without attracting discussion or analysis. But see Adam Steinman, The Pleading Problem, 62 Stan. L. REv. 1293, 1295 n.9 (2010) (drawing conclusions regarding Twombly's influence from the number of citations the case has received).

12 Bivens v. Six Unknown Federal Narcotics Agents, 403 U.S. 388 (1971) (establishing a private right of action for violation of constitutional rights by federal government officials).

13 See Ashcroft v. Iqbal, 129 S. Ct. 1937, 1943 (2009).

14 Id. at 1942.

15 See, e.g., In re Motor Fuel Temperature Sales Practices Litig., 534 F. Supp. 2d 1214, 1216 (D. Kan. 2008) (applying Twombly in a case claiming consumer fraud).

16507 U.S. 163 (1993).

17544 U.S. 336 (2005). 
rights claims-not specifically listed in Rule 9.18 Dura Pharmaceuticals held that the plaintiff must plead all elements of private damages claims under the securities laws. ${ }^{19}$ Specifically, under the facts of Dura Pharmaceuticals, a plaintiff must plead that the alleged securities fraud caused the loss that the plaintiff allegedly incurred. ${ }^{20}$ Both of those recent pleading authorities are important for properly understanding Iqbal and Twombly.

\section{Plain-Language Interpretation of the Federal Rules}

Leatherman arose in the context of civil rights claims against local law enforcement officers. Many courts and commentators at the timeincluding the two lower courts in Leatherman ${ }^{21}$ - believed that the chilling effect on the work of law enforcement officers and municipal defendants, created by the expense and inconvenience of defending against private litigation, necessitated holding those claims to a "heightened" pleading standard. ${ }^{22}$ A circuit split had developed over the question of heightened pleading in civil rights claims against municipalities and local officials entitled to qualified immunity. ${ }^{23}$ The Supreme Court reversed the Fifth Circuit in Leatherman. ${ }^{24}$ It unanimously accepted a plain language interpretation of Rule 9(b) and held that because civil rights claims were not in the enumerated list of claims subject to heightened pleading by Rule 9, requiring pleading with particularity was error. ${ }^{25}$ That rule would apply equally to antitrust claims, as in Twombly, and Bivens actions, as in Iqbal, neither of which is enumerated in Rule 9. ${ }^{26}$

Leatherman did, however, leave open a substantive route to treating antitrust claims differently from other claims. The defendants in that case argued that "the degree of factual specificity required of a complaint by the Federal Rules of Civil Procedure varies according to the complex-

18 Leatherman, 507 U.S. at 168. Rule 9(b) provides, in relevant part: "In alleging fraud or mistake, a party must state with particularity the circumstances constituting fraud or mistake." FED. R. Civ. P. 9(b).

19 See Dura Pharm., 544 U.S. at 346.

20 Dura Pharm., 544 U.S. at 346-47.

21 See Leatherman v. Tarrant Cnty. Narcotics \& Intelligence Unit, 954 F.2d 1054 (5th Cir. 1992).

22 Id. at 1056-59 (explaining the reasons for a rule requiring the plaintiffs to plead their claims with particularity, which echo the reasons underlying the Court's conclusions in Twombly and Iqbal).

23 See Leatherman, 507 U.S. at 165.

24 See id. at 168.

25 See id.

26 Leatherman, then, forecloses one procedural route to treating antitrust claims differently from other sorts of claims. Leatherman does not necessarily end the procedural analysis, however. One of us has argued for another procedural approach, based on plain-language interpretations of Rules 8(a), 8(f), and 12(b)(6). See Huffman, The Necessity of Pleading Elements in Private Antitrust Conspiracy Claims, supra note 7, at 635-45. 
ity of the underlying substantive law." 27 That approach, which the Court did not reject, seemingly allowed a complex claim requiring circumstantial proof of conduct, or proof of the effects of conduct, to be held to an ostensibly higher standard than a simple tort claim. ${ }^{28}$ But as we show infra, it is not the complexity of the claim, but the burden of discovery, that drives the closer scrutiny of allegations in a complaint.

When Leatherman was decided, it set a ceiling for the specificity of allegations necessary to state claims for any but the causes of action referenced in Rule 9(b). The Rule 8 pleading standard was held to be transsubstantive and to apply to all other claims. ${ }^{29}$ While Twombly altered courts' and commentators' understanding of the Rule 8 pleading standard, Leatherman's trans-substantivity endured, setting a floor for the minimum specificity required of allegations. Leatherman seemingly mandated that Twombly not be limited to antitrust claims. Thus, when Iqbal came up for decision, the application of the Twombly rule was foreordained.

\section{Pleading Elements}

Dura Pharmaceuticals involved a claim of fraud in the purchase or sale of securities under SEC Rule 10b-5. ${ }^{30}$ The claim required proof of six elements, including "loss causation." ${ }^{31}$ Loss causation is the existence of a proximate causal link between a material misrepresentation and the plaintiff's loss. The Dura Pharmaceuticals Court held that the failure to plead loss causation undermined the notice to the defendant that Rule 8 and Conley required. ${ }^{32}$ Dura Pharmaceuticals holds simply that the notice requirement of Conley demands that the plaintiff plead facts creating an inference on each element of the plaintiff's claim.

The Dura Pharmaceuticals decision descends from a long tradition of judicial skepticism toward private business tort litigation. That skepticism started with securities law claims, notably Blue Chip Stamps $v$. Manor Drug Stores. ${ }^{33}$ In 1983, the skepticism was imported into anti-

27 Leatherman, 507 U.S. at 167.

28 See Huffman, The Necessity of Pleading Elements in Private Antitrust Conspiracy Claims, supra note 7, at 640-41 (contrasting the complexity of pleading a conspiracy claim with the simplicity of pleading a negligence claim in the case of an automobile accident).

29 See Leatherman, 507 U.S. at 168.

30 See Dura Pharm., Inc. v. Broudo, 544 U.S. 336, 341 (2004) (citing 15 U.S.C. § 78j(b) and 17 C.F.R. $\S 240.10 b-5)$.

31 Dura Pharm., 544 U.S. at 341-42.

$32 \mathrm{Id}$. at 346. Although securities fraud claims are in many contexts subject to a heightened pleading standard under the Private Securities Litigation Reform Act of 1995, 15 U.S.C. $\S 78 \mathrm{u}-4(\mathrm{~b})$, the Dura Pharmaceuticals Court assumed "at least for argument's sake, that neither the Rules nor the securities statutes impose any special further requirement in respect to the pleading of proximate causation or economic loss." 544 U.S. at 346.

33 Blue Chip Stamps v. Manor Drug Stores, 421 U.S. 723 (1975). 
trust law via dictum from Justice Stevens' opinion for the Supreme Court in Associated General Contractors v. California State Council of Carpenters. ${ }^{34}$ The overriding concern in those business tort cases is one of "strike suits" brought by enterprising plaintiffs' counsel resulting in settlements unrelated to the merits of claims or-in the rare case that a case makes it to trial-jury verdicts that drive companies into bankruptcy imposed by juries with wealth-transfer impulses. ${ }^{35}$ Given the wariness toward strike suits, the false positive rationale is deeply embedded in the Court's Rule 8 jurisprudence.

The primary teaching of Dura Pharmaceuticals relates to the process of evaluating complaints for sufficiency. Dura Pharmaceuticals makes clear that the sufficiency of a complaint is analyzed on an element-by-element basis.

\section{B. Twombly}

Twombly involved claims by a purported class of plaintiffs made up of all users of telephone and internet services in the United States from the date of the deregulation of local telephone service in February 1996. ${ }^{36}$ The plaintiffs alleged that the defendant-local telephone companies (1) had conspired not to compete with one another in their respective monopoly service markets ${ }^{37}$ and (2) had conspired to prevent would-be new entrants from gaining toe-holds in their respective markets. ${ }^{38}$ The market allocation would be a hard core, per se violation of the Sherman Act if properly pleaded and proved. ${ }^{39}$

The dispute centered on the sufficiency of plaintiffs' allegations regarding the defendants' agreement. The plaintiffs alleged circumstantial evidence of the agreement, as opposed to direct evidence that the defend-

34 Associated Gen. Contractors, Inc. v. Cal. State Council of Carpenters, 459 U.S. 519, 528 n.17 (1983).

35 See, e.g., Blue Chip Stamps, 421 U.S. at 740-42.

36 The purported class was comprised of "subscribers of local telephone and/or high speed internet services . . . from February 8, 1996 to present." Bell Atlantic Corp. v. Twombly, 550 U.S. 544, 550 (2007).

37 See id. at 551 ("Second, the complaint charges agreements by the ILECs to refrain from competing against one another. Those are to be inferred from the ILECs' common failure 'meaningfully [to] pursu[e]' 'attractive business opportunit[ies]' in contiguous markets where they possessed 'substantial competitive advantages,' and from a statement of the chief executive officer (CEO) of the ILEC Qwest, that competing in the territory of another ILEC "might be a good way to turn a quick dollar but that doesn't make it right."').

$38 I d$. at 550 ("Plaintiffs say, first, that the ILECs 'engaged in parallel conduct' in their respective service areas to inhibit the growth of upstart CLECs.”).

39 See Palmer v. BRG of Ga., Inc., 498 U.S. 46 (1990) (holding horizontal market division illegal per se); see also Federal Trade Commission and U.S. Department of Justice, Antitrust Guidelines for Collaborations Among Competitors $\$ 3.2$ (2000), available at http://www.ftc.gov/os/2000/04/ftcdojguidelines.pdf. 
ants or their representatives had met and formed an agreement. ${ }^{40}$ The plaintiffs also alleged the following circumstantial facts supporting their views that the observed conduct must have resulted from a conspiracy: the defendants' territorial markets appeared gerrymandered, the defendants were members of trade organizations that gave them opportunities to meet and to reach agreement, ${ }^{41}$ and the CEO of one defendant had said publicly that entering into competition as a new entrant "might be a good way to turn a quick dollar, but that doesn't make it right." 42 The Twombly plaintiffs alleged the ultimate legal fact: "upon information and belief that Defendants have entered into a contract, combination or conspiracy." 43

The Court held the complaint insufficient, reversing the court of appeals and reinstating the district court's dismissal. By requiring that the allegations create a "plausible inference" of an agreement among the defendants, the Supreme Court applied to the complaint a procedural standard that courts had, for decades, used in antitrust cases on motions for judgment as a matter of law. ${ }^{44}$ The Court had never before adopted that standard for the motion to dismiss for failure to state a claim under

40 See Amended Complaint paras. 37-51, Twombly, 550 U.S. 544 (2007) (No. 02 CIV. 10220), 2003 WL 25629874.

41 Trade association membership is a common allegation in concerted conduct antitrust litigation. See, e.g., F.T.C. v. Ind. Fed'n of Dentists, 476 U.S. 447 (1986) (dental association rule prohibiting dentists from submitting x-rays in connection with insurance forms alleged to be illegal); Nw. Wholesale Stationers, Inc. v. Pac. Stationery \& Printing Co., 472 U.S. 284 (1985) (cooperative association sued for expelling plaintiff for violating bylaw preventing members from participating as wholesalers and retailers).

42 Twombly, 550 U.S. at 551 (noting allegations made in the complaint by "Richard Notebaert, chief executive officer (CEO) of the ILEC Qwest, that competing in the territory of another ILEC 'might be a good way to turn a quick dollar but that doesn't make it right"). Plaintiffs inferred from the statement that not taking advantage of the available "quick dollar" was best explained by the existence of a conspiracy.

43 The complaint couches its penultimate allegations this way:

In the absence of any meaningful competition between the [ILECs] in one another's markets, and in light of the parallel course of conduct that each engaged in to prevent competition from CLECs within their respective local telephone and/or high speed internet services markets and the other facts and market circumstances alleged above, Plaintiffs allege upon information and belief that [the ILECs] have entered into a contract, combination or conspiracy to prevent competitive entry in their respective local telephone and/or high speed internet services markets and have agreed not to compete with one another and otherwise allocated customers and markets to one another.

Id. (citations omitted) (quoting the complaint). That allegation, if it were to have been treated as sufficient, would by itself have fulfilled the plaintiffs' pleading burden because of the irrebuttable presumption of market effects in a claim of per se illegal market allocation under $\S 1$. See Palmer, 498 U.S. 46, 49-50 (1990).

44 Twombly, 550 U.S. at 556 (plausibility standard); see Edward Brunet, Antitrust Summary Judgment and the Quick Look Approach, 62 SMU L. REv. 493, 511 (2009). 
Federal Rule of Civil Procedure 12(b)(6). ${ }^{45}$ The "mere possibility" stan-
dard from the Second Circuit was "short of the line." 46

An inference of conspiracy from the plaintiffs' factual allegations was insufficiently plausible to permit discovery in Twombly. The Court addressed the allegations singly. ${ }^{47}$ Allegations of parallel inhospitality to entry and parallel failure to enter spoke at most to interdependent conduct (which does not amount to an agreement). ${ }^{48}$ While the plaintiffs'

45 See Twombly, 550 U.S. at 554-55 (cataloguing prior decisions and noting "this case presents the antecedent question of what a plaintiff must plead in order to state a claim"); see also Richard A. Epstein, Bell Atlantic v. Twombly: How Motions to Dismiss Become (Disguised) Summary Judgment Motions, 25 WASH. U. J.L. \& PoL'y 61, 62 (2007) (arguing the Court's analysis is "flawed . . . In reality, Twombly III was a disguised motion for summary judgment ...."). Other scholars agree that the Court's analysis in Twombly is flawed, but many, unlike Professor Epstein, believe the wrong result was reached. See, e.g., Amy Wildermuth, What Twombly and Mead Have in Common, 102 Nw. U. L. Rev. Colloquy 276, 280 (Apr. 11, 2008) (describing a "spinning sensation" on reading Twombly).

46 Twombly, 550 U.S. at 546. Scholars interested in civil procedure have been understandably befuddled by the various terms used to describe the appropriate probability of illegal conduct based on the allegations in the complaint. The Supreme Court settled on "plausibility," but the Second Circuit had used "plausible possibility." Twombly v. Bell Atlantic Corp., 425 F.3d 99, 111 (2d Cir. 2004) (citing Todd v. Exxon Corp., 275 F.3d 191, 197 (2d Cir. 2001)) (applying a plausibility test to market definition by stating that "conspiracy must be among the range of plausible possibilities"). The distinction between "plausible inference" and "plausible possibility" is latent, if it exists at all. The inability to draw helpful conclusions from the terminology used demonstrates the need to understand Twombly from the perspective of substantive antitrust law rather than civil procedure standards. See Brunet, supra note 44, at 511 (stating that Twombly "only makes sense if characterized as a matter of substantive antitrust law").

47 The approach of addressing plaintiffs' allegations singly might be inappropriate. See Continental Ore Co. v. Union Carbide \& Carbon Corp., 370 U.S. 690, 699 (1962) (holding that "plaintiffs should be given the full benefit of their proof without tightly compartmentalizing the various factual components and wiping the slate clean after scrutiny of each"). If Twombly does depart from Continental Ore, because the earlier case arose at the directed verdict stage of litigation, Twombly, in treating the allegations individually, might be thought to require a stronger demonstration at the motion to dismiss stage than at later stages of litigation.

48 The district court had recognized independent explanations for some of the observed conduct. The district court noted that the service markets took the shape they did as a result of historical accident during the period of regulated monopoly in local telephone service. See Twombly v. Bell Atlantic Corp., 313 F. Supp. 2d 174, 182-83 (S.D.N.Y. 2003). It also rejected the inference of agreement the plaintiffs drew from the defendants' acting in parallel fashion in refusing to be hospitable to new entry. That conduct would be in each defendant's unilateral best interest. The fact that they all did it, then, did not support an inference of an agreement. See id. at 184 . There was also an independent explanation for the defendants' mutual failures to enter into competition. The district court and the Supreme Court recognized the fundamentally different nature of the business model of a new entrant competitor from that of an incumbent telephone service provider. Each defendant had an independent reason not to enter other service markets as a new entrant because its business was not structured such that the firm would be likely to succeed in competing as a new entrant. Success at one endeavor did not guarantee success at the other. See id. at 185-87; see also Twombly, 550 U.S. at $568-69$.

The theory of interdependence recognizes that firms that are not monopolists make decisions with an eye toward the expected impact of their decisions on their competitors. See Robert S. Pindyck \& Daniel L. Rubinfeld, Microeconomics 430 (5th ed. 2001). The law 
allegations were not inconsistent with a conspiracy, they did not exclude the possibility of unilateral conduct. ${ }^{49}$ The allegations, therefore, did not create a plausible inference. The plaintiffs' other allegations were entirely neutral with regard to the question of agreement. A plausible inference requires more.

What was missing in Twombly was an allegation that was anything other than purely neutral as to whether the defendants had conspired. Such an allegation could be direct - "the defendants met in a hotel room in Des Moines" - or circumstantial- "the observed conduct could not have occurred but for an agreement." The plaintiffs made neither form of permissible allegation. Therefore, the agreement element of the $\S 1$ claim was not sufficiently pleaded.

At bottom, Twombly was about the burden of defending against private antitrust claims. For that reason as well, Dura Pharmaceuticals is its natural progenitor. The concern for undue burden in private claims has a long history in private securities litigation, reaching as far back as Blue Chip Stamps.

\section{Iqbal}

The Court recently clarified that the Twombly standards are not unique to antitrust cases. The imposition of an undue burden on defendants from discovery in spurious cases-a driving concern underlying Twombly - is not unique to the false positive concerns that underlie modern antitrust courts' skepticism with regard to private claims. The requirement of pleading substantive law, which Twombly borrowed from Dura Pharmaceuticals, carries over into other legal arenas. Iqbal offers a fresh take on the application of the Rule 8 standard.

on interdependence was well established decades before the Twombly litigation began. The rule is also solidly grounded in antitrust economics, although Richard Posner famously disagrees. See Michael D. Whinston, Lectures on Antitrust Economics 52-55 (2006) (noting the challenges of remedying tacit collusion: "Can we tell them 'Do not tacitly collude'? Or 'Do not make your pricing decisions with regard to what your rivals do'?' (citing Donald F. Turner, The Definition of Agreement under the Sherman Act: Conscious Parallelism and Refusals to Deal, 75 Harv. L. Rev. 655 (1962)); James A. Rahl, Conspiracy and the Anti-Trust Laws, 44 ILl. L. REv. 743 (1950) (noting practical problems with attacking consciously parallel conduct as conspiratorial, which ultimately leads to prosecutions based on mere structure rather than conduct); Donald F. Turner, The Definition of Agreement under the Sherman Act: Conscious Parallelism and Refusals to Deal, 75 Harv. L. Rev. 655 (1962) (noting the challenges of remedying conscious parallelism). But see Richard A. Posner, Antitrust Law 55-60 (2d ed. 2001) (arguing it is possible to outlaw and to remedy tacit collusion); Richard A. Posner, Oligopoly and the Antitrust Laws: A Suggested Approach, 21 Stan. L. Rev. 1562 (1969). See generally Keith N. Hylton, Antitrust Law 74-89 (2005) (critiquing the arguments from Rahl to Posner).

49 Twombly, 550 U.S. at 554 (finding no "factual context suggesting agreement, as distinct from identical, independent action"). 
Iqbal presents a dramatic extension of Twombly's principles. Twombly required a plaintiff to plead facts about conduct that were best, if not uniquely, knowable to the defendants themselves. Iqbal requires a plaintiff to plead facts about personal motivation that may be known only to the defendants. ${ }^{50}$

\section{The Story of Iqbal}

In Iqbal, Muslim men including the named-plaintiff Iqbal sued thenAttorney General John Ashcroft and FBI Director Robert Mueller, alleging mistreatment following the September 11th attacks. ${ }^{51}$ The complaint alleged that Ashcroft and Mueller had each violated the plaintiffs' constitutional rights through purposeful discrimination on the basis of a prohibited characteristic, whether race (Arab), religion (Muslim), or national origin (Pakistani). ${ }^{52}$ Iqbal alleged that Ashcroft was the "principal architect" of a discriminatory policy and that Mueller was "instrumental." 53 The complaint alleged that together they "knew of, condoned, and willfully and maliciously agreed" to mistreat Iqbal for discriminatory reasons lacking any "legitimate penological interest." 54

In order to prevail on this cause of action, Iqbal was required to plead, and ultimately to prove, that the defendants "acted with discriminatory purpose." 55 To prove that the defendants had acted with discriminatory purpose, Iqbal would have to prove that the actions of Ashcroft and Mueller were undertaken because of his membership in a protected class. ${ }^{56}$

The Supreme Court held that Bivens actions do not create respondeat superior liability, ${ }^{57}$ unlike in antitrust law. Ashcroft and Mueller must have acted each, individually with an impermissible purpose. It would not be sufficient to allege that they were liable for conduct of their subordinates..$^{58}$ Bivens actions are also subject to the defense of qualified immunity, which shields government officials from personal damages liability and suit, so long as the alleged conduct does not violate clearly established constitutional rights. ${ }^{59}$

50 Unlike antitrust claims, the civil rights claims in Iqbal do not permit respondeat superior liability. Ashcroft v. Iqbal, 129 S. Ct. 1937, 1949 (2009). Thus, a suit against an individual must be based on the individual's conduct, which may be known only to him or her.

51 See id. at 1942.

52 See id. at 1943-44.

53 Id. at 1944 (2009) (quoting Complaint III 10, 11).

54 Id. (Complaint II 96).

55 Id. at 1948 (citing Church of Lukumi Babalu Aye, Inc. v. Hialeah, 508 U.S. 520, 540-41 (1993), and Washington v. Davis, 426 U.S. 229, 240 (1976)).

56 Id.

57 See id. at 1949.

58 Id. at 1949.

59 Harlow v. Fitzgerald, 457 U.S. 800, 818 (1982). 


\section{Iqbal's Analysis of Twombly}

The Court in Iqbal identified "two working principles" in Twombly. ${ }^{60}$ The first principle the Court identified was the prohibition against pleading legal conclusions. ${ }^{61}$ That principle is noncontroversial. ${ }^{62}$ The second principle is that in order to survive the motion to dismiss, the claim for relief must be plausible in light of the facts alleged. That requirement finds support in Rule 8's requirement that the complaint "show" entitlement to relief.63 Once legal conclusions are discarded, the well-pleaded facts must "plausibly suggest" unlawful conduct. ${ }^{64}$ Commentators have treated the plausibility rule with substantial disdain. ${ }^{65}$ What precisely constitutes a "plausible" showing, rather than the insufficient "possibility" 66 or the unnecessary "probability,"67 is unknowable.

Iqbal explained that Twombly held the complaint insufficient because the nonconclusory allegations of parallel conduct were "not only compatible with, but indeed [were] more likely explained by, lawful, unchoreographed free-market behavior." 68 In analyzing the complaint, the Iqbal majority discarded the conclusory allegations. It then posed a choice between two competing rationales for the observed disparate impact of post-September 11th detention policies. The first proffered ratio-

60 Iqbal, 129 S. Ct. at 1949.

61 Id. (citing Bell Atlantic Corp. v. Twombly, 550 U.S. 544, 555 (2007)); see also Tal v. Hogan, 453 F.3d 1244, 1261 (10th Cir. 2006); DM Research, Inc. v. College of American Pathologists, 170 F.3d 53 (1st Cir. 1999); Sutliff, Inc. v. Donavan Cos., 727 F.2d 648, 654 (7th Cir. 1984); Heart Disease Research Found. v. General Motors Corp., 463 F.2d 98, 100 (2d Cir. 1972); Christopher M. Fairman, The Myth of Notice Pleading, 45 ArIz. L. REv. 987, 999 (2003) ("Broad statements of legal conclusion do not meet the pleading requirements under the Federal Rules . . . ."); Richard L. Marcus, The Revival of Fact Pleading Under the Federal Rules, 86 Colum. L. Rev. 433, 435 (1986) (noting "a number of areas in which courts refuse to accept 'conclusory' allegations as sufficient under the Federal Rules"). See generally Huffman, The Necessity of Pleading Elements in Private Antitrust Conspiracy Claims, supra note 7, at 640-41 (canvassing authorities interpreting the prohibition on conclusory allegations post-Twombly).

62 Charles E. Clark, the principal drafter of the Federal Rules and a proponent of the notice pleading standard, considered it "settled" that "the pleader shows the facts and the court applies the legal conclusion." Charles E. Clark, Special Pleading in the "Big Case”, 21 F.R.D. 45, 52 (1957). Commentators have, however, argued that the Federal Rules endorse legal conclusions in certain circumstances. See Scott Dodson, Pleading Standards After Bell Atlantic Corp. v. Twombly, 93 VA. L. Rev. IN BRIEF 121, 141 (2007) (noting conclusory allegations of "negligence" and "recklessness" were specifically endorsed by Form Complaints 9 and 10 to the Federal Rules); A. Benjamin Spencer, Plausibility Pleading, 49 B.C. L. REv. 431, 442 (2008) (same).

63 Iqbal, 129 S. Ct. at 1950.

64 See id.

65 See, e.g., Spencer, supra note 62, at 460-89.

66 See Iqbal, $129 \mathrm{~S}$. Ct. at 1950 (finding "mere possibility" insufficient).

67 Bell Atlantic Corp. v. Twombly, 550 U.S. 544, 556 (2007) (stating that the Supreme Court "does not impose a probability requirement at the pleading stage").

68 Iqbal, 129 S. Ct. at 1950. 
nale was Iqbal's preferred inference: Ashcroft and Mueller, individually or collectively, ${ }^{69}$ intended to discriminate against Arab Muslim men, thus amounting to a constitutional violation. ${ }^{70}$ Another possibility was that a post-September 11th detention policy, purely neutral toward race, religion, and national origin, would present the same observed disparate impact because, as the Supreme Court noted:

The September 11 attacks were perpetrated by 19 Arab Muslim hijackers who counted themselves members in good standing of al Qaeda, an Islamic fundamentalist group. Al Qaeda was headed by another Arab MuslimOsama bin Laden-and composed in large part of his Arab Muslim disciples. It should come as no surprise that a legitimate policy directing law enforcement to arrest and detain individuals because of their suspected link to the attacks would produce a disparate, incidental impact on Arab Muslims, even though the purpose of the policy was to target neither Arabs nor Muslims. ${ }^{71}$

The Court preferred the latter, "obvious alternative explanation." 72

\section{A Dissenting View}

Justice Souter, the author of Twombly, dissented in Iqbal. He believed that the substantive legal principle of no supervisory liability, on which the Court relied, was erroneous. ${ }^{73}$ Under Souter's position, allegations of fact giving rise to a plausible inference of individual discriminatory animus on the parts of Ashcroft and Mueller would be unnecessary. Due to their disagreement about the question of supervisory liability, the majority and the dissent in Iqbal are somewhat like ships passing in the night with regard to the meaning of Twombly.

Justice Souter did, however, argue that the majority had misapplied Twombly. He believed the allegations that Ashcroft was the "principal architect" of the discriminatory policies, that Mueller was "instrumental in the[ir] adoption," and that the two "knew of, condoned, and wilfully and maliciously agreed to subject" plaintiff to conditions of confinement "solely on account of his race, religion and/or national origin and for no

69 Unlike the $\S 1$ claim at issue in Twombly, nothing about the Bivens action in Iqbal turns on the existence of a conspiracy between Ashcroft and Mueller. Unilateral discriminatory motive on the part of either official would be a basis for a Bivens claim against that official.

70 Iqbal, 129 S. Ct. at 1951.

$71 \mathrm{Id}$.

72 Id. at 1951-52.

73 Id. at 1957-58 (Souter, J., dissenting). 
legitimate penological interest" were sufficient to meet the Twombly pleading standard. ${ }^{74}$

Reading the dissent compels the question of why Justice Souter found a bare assertion of "conspiracy" insufficient to meet the Rule 8 standard in Twombly, yet found the bare assertion of "malicious intent" sufficient in Iqbal. The assertions in each case are legal conclusions. The best explanation lies in the complexity of the concept of conspiracy in antitrust cases, in contrast to the relative simplicity of the concept of discriminatory motive in civil rights cases. The assertion that defendants conspired gave insufficient notice to the Twombly defendants of the conduct in which they, or their agents, were supposed to have engaged. A charge of conspiracy invokes a functionally infinite number of different factual scenarios where large organizational defendants, acting through agents, are concerned. In the antitrust context, it also invokes difficult and unsettled legal questions of what forms of coordinated conduct in an oligopoly setting actually meet the legal standard of conspiracy. Conversely, allegations that actions were motivated solely by race, religion, or national origin do not involve such factual or legal complexity. ${ }^{75}$

\section{Overreaching}

Iqbal went further than Twombly on a surface level because Twombly could reasonably be thought limited, prior to Iqbal, to antitrust claims generally, or even to antitrust conspiracy claims specifically. Iqbal now has clarified that Twombly applies equally to all federal civil litigation. ${ }^{76}$ Iqbal also outpaced Twombly because, given the lack of respondeat superior liability and the consequent reliance on the defendants' individual motives, the information necessary to establish Iqbal's claims was more likely to be uniquely held by the individual defendants from whom discovery is not allowed. The information necessary to plead the plaintiff's claim was semi-public in nature due to the Twombly defendants' organizational structures. Statements made by a disgruntled or loose-lipped employee would be sufficient for plaintiffs to make their allegations. ${ }^{77}$

Iqbal also extended the application of the plausibility standard from a substantive legal subject area in which decades of economic research have shaped the substantive rule of law to one in which defendants' sub-

74 Id. at 1959 (Souter, J., dissenting).

75 This "conclusory" allegation posed by the Bivens action in Iqbal is thus most closely comparable to the allegation of "negligence" expressly approved in Form 9 to the Federal Rules. See Huffman, The Necessity of Pleading Elements in Private Antitrust Conspiracy Claims, supra note 7, at 640-41.

76 Iqbal, 129 S. Ct. at 1953.

77 Allegations of a Sherman Act $\S 1$ conspiracy between sole proprietors would present a more precise analogy to the circumstance of Iqbal. 
jective motivations are insufficiently understood. The Twombly Court relied on economic teachings, which remain largely undisturbed in modern literature: ${ }^{78}$ rational, profit-maximizing competitors, faced with an oligopolistic marketplace, and who have been granted monopoly service territories by past government policy, are likely to unilaterally decide not to enter into direct competition. The Supreme Court received support for that proposition via scholarly writings and amicus curiae briefs submitted in the litigation by antitrust law scholars and economists. ${ }^{79}$ Those economic principles had become part of the substantive rule of law in antitrust conspiracy cases decades before Twombly was decided. ${ }^{80}$

No such deep social science authority supported the conclusion in Iqbal that "as between that 'obvious alternative explanation' [of simple, disparate impact of a neutral policy] . . . and the purposeful, invidious discrimination respondent asks us to infer, discrimination is not a plausible conclusion." 81 The Supreme Court in Iqbal did not cite any psychological, sociological, or penological studies regarding government officials' subjective motivations for detention policies in the wake of cataclysmic events. ${ }^{82}$ Iqbal's most dramatic extension of Twombly is the Supreme Court's appropriation of the power to conclude for itself which inferences, to be drawn from observed facts, are "plausible" and which are not.

78 But see Maurice Stucke, Behavioralists at the Gate, 38 Loy. U. CHI. L.J. 513 (2007) (arguing that behavioral economics suggests likely rationales for corporate conduct other than unilateral profit maximization).

79 See, e.g., Brief of Amici Curiae Economists in Support of Petitioners, 8-9, Bell Atlantic Corp. v. Twombly, 550 U.S. 544 (2007) (No. 05-1126), 2006 WL 2506633; Brief for Legal Scholars as Amici Curiae in Support of Petitioners, Bell Atlantic Corp. v. Twombly, 550 U.S. 544 (2007) (No. 05-1126), 2006 WL 2474080; 6 Phillip Areeda \& Herbert HovenKamp, Antitrust Law II 1410a (2d ed. 2003) [hereinafter Areeda \& Hovenkamp]; 2 Joseph P. Bauer \& William H. Page, Kintner's Federal Antitrust Law $§ 11.5$ (2d ed. 2002).

80 See generally Huffman, The Necessity of Pleading Elements in Private Antitrust Conspiracy Claims, supra note 7, at 645-57 (discussing the adoption of economic principles in $\S 1$ conspiracy claims from 1954 through 1993).

81 Iqbal, 129 S. Ct. at 1951-52.

82 The historical data and scholarship presented to the Supreme Court in Iqbal rather supports the view that plaintiff Iqbal's allegations of race, religion and national-origin-based animus were plausible. One amici brief noted that racial animus historically motivated detention policies analogous to those complained of in Iqbal. See Brief of Amici Curiae JapaneseAmerican Citizens League et al. in Support of Respondents at 13-15, Ashcroft v. Iqbal, $129 \mathrm{~S}$. Ct. 1937 (2009) (No. 07-1015), 2008 WL 4805228 (citing Hirabayashi v. United States, 320 U.S. 81 (1943)) (noting historical support for an understanding of disparate impact of detention policies following national crises being based on animus rather than race or national origin-neutral security concerns); see also Nelson Lund, The Conservative Case Against Racial Profiling in the War on Terrorism, 66 ALB. L. Rev. 329 (2003). Lund discussed public opinion polls strongly supporting racial profiling of Arab men post September 11, id. at 330 \& nn. $6-7$, the ineradicable nature of racial profiling in human interactions and the inability of governments (as distinct from the private sector) to rely on market forces to overcome it, $i d$. at 332-33, 335-38; and Hirabayashi and Korematsu v. United States, 323 U.S. 214 (1944) as examples of government misuse of racial profiling, $i d$. at 339-40. 


\section{Unifying Rationales}

The pleading standards set forth in Iqbal and Twombly share the unifying rationale that avoidance of litigation per se-independent of any resulting liability -is a sufficiently worthy goal to restrict court access to plaintiffs. A concern for the potential chilling effect on firms' beneficial conduct that could be caused by over-enforcement by private plaintiffs was crucial to Twombly and its antitrust and securities law ancestry. ${ }^{83}$ The Twombly Court devoted much of its opinion to a discussion of the importance of avoiding burdensome discovery in private Sherman Act litigation. ${ }^{84}$ That concern has manifested itself in private antitrust cases since the Supreme Court's 1983 Associated General Contractors opinion, which noted in a footnote that the "massive factual controversy" at issue gave the district court power to "insist on greater specificity in the pleadings." 85 The Twombly Court cited several sources for the proposition that discovery in antitrust litigation is extraordinarily expensive and noted the decades-old dictum imported from private securities litigation that expensive discovery increases settlement value disproportionately to the merits of plaintiffs' claims. ${ }^{86}$

83 Bell Atlantic Corp. v. Twombly, 550 U.S. 544, 555, 556-60 (2007) (regarding the problem of false positives and concerns about abusive discovery: "proceeding to antitrust discovery can be expensive"). This concern may be limited to private antitrust enforcement. $C f$. Daniel Crane, Antitrust Antifederalism, 96 CAL. L. Rev. 1, 38-40 (2008) (arguing that the "pathology" of excessive reliance on private litigation in antitrust undermines just outcomes and overwhelms public enforcement); Max Huffman, Bridging the Divide? Theories for Integrating Competition Law and Consumer Protection, 6 EuR. Competition J. 7, 23-25 (2010) (discussing the differences between private and public enforcement).

84 Twombly, 550 U.S. at 560 n.6. This portion of the Court's opinion in Twombly has been roundly criticized on several grounds. The Court relied on securities law precedents in articulating its concern that discovery can be abusive and out of proportion to the merits. The Court failed, however, to draw the necessary link between securities and antitrust claims, except for listing several authorities that described antitrust discovery in qualitative terms, and considering it "obvious enough" that discovery will be "sprawling, costly, and hugely timeconsuming." The Court did not rely on quantitative analysis of discovery expense in antitrust suits, which does not appear to exist in current literature.

85 Associated Gen. Contractors of Cal., Inc. v. Cal. State Council of Carpenters, 459 U.S. 519, 528 n.17 (1983). Earlier examples of concern for discovery expense in antitrust litigation are not readily known, but hostility to private litigation has its roots in the neo-classical economic revolution in antitrust that took root in the 1970s and was given the Supreme Court's imprimatur in a series of cases in 1977, including Brunswick Corp. v. Pueblo Bowl-o-Mat, 429 U.S. 477 (1977) and Continental T. V., Inc. v. GTE Sylvania Inc., 433 U.S. 36 (1977).

86 Twombly, 550 U.S. at 558-60 (citing Blue Chip Stamps v. Manor Drug Stores, 421 U.S. 723, 741 (1975), and cases and commentators speaking about discovery expense in antitrust cases). The concern for "blackmail settlements" in private litigation has a long pedigree. See, e.g., Henry Friendly, Federal Jurisdiction 120 (1973) (citing Milton Handler, The Shift from Substantive to Procedural Innovations in Antitrust Suits-the Twenty-Third Antitrust Review, 71 Colum. L. Rev. 1, 9 (1971)) (expressing the concern that civil class-action litigation "produce[s] blackmail settlements"). In the securities arena, discovery expense was one of the driving factors behind legislation limiting private rights of action. 
Even Justices Stevens and Ginsburg, who dissented in Twombly, accepted the Court's portrait of the realities of antitrust litigation: "Private antitrust litigation can be enormously expensive, and there is a risk that jurors may mistakenly conclude that evidence of parallel conduct has proved that the parties acted pursuant to an agreement . . . ."87 Justices Stevens and Ginsburg believed those concerns warranted care in case management but not a departure from settled procedures for pleading and proving cases.

Iqbal turned on special concerns for harm from forcing government defendants to undergo burdensome litigation, including "disruptive discovery." 88 Justice Kennedy, writing for the majority, stated that "[1]itigation ... exacts heavy costs in terms of efficiency and expenditure of valuable time and resources that might otherwise be directed to the proper execution of the work of the Government."89 Like the antitrust claim in Twombly and the private securities claims in cases such as Dura Pharmaceuticals, on which Twombly relied, the Bivens action in Iqbal was held to present a sufficiently intolerable risk of harm from litigation to justify restrictions on plaintiffs' access to federal courts. ${ }^{90}$ Such suspicion of suits against government officials, particularly in law enforcement or security settings, also has a long history. ${ }^{91}$ Reliance on motions to dismiss to protect against the threat of social harm from excessive private enforcement is well established in the civil rights arena, perhaps even more than in the context of commercial torts.92 Part II develops a framework for application of these unifying rationales for heightened pleading standards to all civil claims in federal court.

87 Twombly, 550 U.S. at 573 (Stevens, J., dissenting).

88 Ashcroft v. Iqbal, 129 S. Ct. 1937, 1953 (2009) (Kennedy, J., concurring) (citing Siegert v. Gilley, 500 U.S. 226, 236 (1991)) (expressing concerns about abusive discovery).

89 Id.

$90 \mathrm{Id}$.

91 Cf. Spalding v. Vilas, 161 U.S. 483, 498-99 (1896) (stating, in a suit against highranking postal officer, "It would seriously cripple the proper and effective administration of public affairs as entrusted to the executive branch of the government, if he were subjected to any such restraint. He may have legal authority to act, but he may have such large discretion in the premises that it will not always be his absolute duty to exercise the authority with which he is invested. But if he acts, having authority, his conduct cannot be made the foundation of a suit against him personally for damages, even if the circumstances show that he is not disagreeably impressed by the fact that his action injuriously affects the claims of particular individuals.").

92 See Harlow v. Fitzgerald, 457 U.S. 800, 808 (1982) (citing Butz v. Economou, 438 U.S. 478, 507-08 (1978)) ("Insubstantial lawsuits can be quickly terminated by federal courts alert to the possibilities of artful pleading. Unless the complaint states a compensable claim for relief . . . it should not survive a motion to dismiss."). 


\section{Applying the Twombly/IQbal Framework to Different TYPES OF FACTS}

The pleading standard of Rule 8 controls a plaintiff's access to later stages of the litigation process. Those later stages include the answer, discovery, summary judgment motions, trial, post-trial motions, and appeal. The parties, the court, and the fact-finder gain access to information about the contested facts at those later stages. All other things being equal, more information about contested facts will result in a more accurate determination about the validity of a claim. In a perfect world we would have instant and free access to information about the validity of the plaintiff's claim, without compromising a defendant's legitimate concern for the privacy and security of its sensitive information. In such a world, invalid claims would be identified and instantly dismissed. Valid claims would be quickly vindicated. ${ }^{93}$ However, the imperfection existing in the real world includes the fact that information has costs and is never certain. Rule 8's pleading standard can be used to address those imperfections. Rule 8's standard is designed to attempt to identify when the benefits of moving a case to later stages of litigation outweigh the costs. ${ }^{94}$

\section{A. False Positive Error Can Result from Denying a Motion to Dismiss}

Some litigation costs are easy to spot. Going forward with discovery, motion practice, trial, and appeal involves attorneys' fees, expert expenses, and time. Other costs of moving a case past the complaint stage by denying a motion to dismiss are real but less obvious. One cost of moving a case past the complaint stage is the risk that the litigation will result in false positive error. A false positive occurs when a nonmeritorious claim results in an award or a settlement for the plaintiff. The easiest false positive to understand is an erroneous judgment for the plaintiff following trial and appeal. The litigation process is not perfect and sometimes results in erroneous judgments. Not surprisingly, some of those erroneous judgments are for plaintiffs.

A less obvious false positive occurs when a defendant facing a nonmeritorious claim settles with the plaintiff. A defendant facing a non-

93 Cf. Paul Stancil, Balancing the Pleading Equation, 61 BAYLOR L. REv. 90, 114-16 (2009) (making an economic defense of notice pleading, and comparing the "net social welfare decrease[ ]"- where plaintiffs cannot bring claims because of lack of necessary information to meet the pleading standard-with the "economic costs" of notice pleading).

94 Rule 8 includes sub-part 8(e), which instructs courts: "All pleadings shall be so construed as to do substantial justice." FED. R. Civ. P. 8(e). See Huffman, The Necessity of Pleading Elements in Private Antitrust Conspiracy Claims, supra note 7, at 644-45 (interpreting Rule 8(e) to grant courts discretion to consider complaints more deeply than the concept of "notice pleading" suggests is appropriate). 
meritorious claim must confront the likely expenses of defendingattorneys' fees, expert expenses, and its employees' time. It must also face the possibility that even if it fully litigates the matter, it might still end up losing because the litigation process is imperfect. Given those expense considerations, it may be rational for the defendant to settle nonmeritorious claims. ${ }^{95}$

A third manifestation of false positive error occurs when potential defendants are deterred from engaging in desirable activity because of the threat of litigation. Recognizing ex ante the danger of incurring discovery expenses and possible liability, defendants are motivated to keep well short of the line that separates legal from illegal conduct. In eschewing legal conduct that may give rise to litigation, defendants dumbdown their conduct to their own, and society's, detriment. That, too, is a cost of false positive error.

The detriment to society caused by false positive error is a product of two factors: (1) whether a false positive error is very likely to occur in a particular setting and (2) if a false positive error does occur, whether it will be very costly. Both of those variables, likelihood and cost, vary depending on the area of substantive law involved. In the next sub-Part, we show that both Twombly and Iqbal involve areas of substantive law where the cost of false positive error, when it occurs, is high.

95 Of course, false negative error may also occur even when the plaintiff survives a motion to dismiss. A fully litigated case might result in an erroneous judgment for the defendant following trial. Further, the same settlement calculus that affects defendants facing nonmeritorious claims affects plaintiffs asserting meritorious claims. In fact, empirical research on the decision-making bias of "loss aversion" suggests that false negative error due to settlement is more likely than is false positive error. See Jeffrey J. Rachlinski, Gains, Losses and the Psychology of Litigation, 70 S. CAL. L. REv. 113, 144 (1996) (presenting empirical research demonstrating that plaintiffs are risk averse in settlement negotiations while defendants are risk-seeking). Due to their risk aversion, plaintiffs may settle a case for less than the full remedy that would be available from fully litigating the claim or even abandon a case without settlement. The plaintiff faces attorneys' fees and related expenses that, in many situations, will not result in a fee award. Also, the plaintiff with a meritorious claim must face the possibility that even if it fully litigates the claim, the litigation process is not perfect and may result in the plaintiff's erroneously losing.

The Rule 8 pleading standard creates another possibility for false negatives, beyond the possibility that a fully litigated case may result in an erroneous judgment and the usual settlement calculus. If Rule 8's pleading standard is not satisfied, the case will be dismissed on a 12(b)(6) motion. This is so even if further litigation would have revealed that the plaintiff's claim is meritorious. For example, in Twombly it is possible that employees of the defendanttelecommunications company actually met somewhere and expressly agreed to divide the country into noncompetitive territories. Because a 12(b)(6) motion was granted, the defendants were not even required to file an answer denying that such an express agreement existed, much less answer questions about that possible agreement under oath. See Bell Atlantic Corp. v. Twombly, 550 U.S. 544, 572 (2007) (Stevens, J., dissenting). If such an agreement had actually taken place, the Court's terminating the plaintiff's case yielded a false negative. An analogous possibility exists in Iqbal. But working within the parameters the Court established in Twombly and Iqbal, this paper focuses on the cost of false positives rather than false negatives. 


\section{B. False Positive Error is Costly in Antitrust and Civil Rights Claims}

False positive error in antitrust over-deters efficient, legal behavior. ${ }^{96}$ False positives under $\S 1$ of the Sherman Act, ${ }^{97}$ which prohibits agreements that unreasonably restrain trade, can occur in several ways. An erroneous judgment or settlement for the plaintiff may occur if an agreement among the defendants did not exist and the concerted action element is not satisfied. Alternatively an error could occur in the application of the reasonableness element of $\S 1$. An erroneous application of the reasonableness element might occur if a per se rule-which outlaws agreements regardless of their effects-was applied to the defendants' behavior, when analysis under the "rule of reason" would reveal that the defendants' behavior was competitively neutral or pro-competitive. ${ }^{98}$ An error in the application of the reasonableness element could also occur under the rule of reason, which requires an inquiry into the net competitive effect of the agreement at issue. A false positive error could occur if the defendants' behavior was competitively neutral or net pro-competitive but nonetheless was the basis for a settlement or verdict. Under any of those scenarios, the defendants' behavior was lawful, but a false positive could occur if the defendants settled or suffered an erroneous judgment.

Such false positive error involves wealth transfers from the defendants to the plaintiffs, and the expenditure of resources by all parties in the litigation. However, the prospect of litigation can also lead to over-deterrence of lawful, efficient behavior. Such over-deterrence is most easily seen in analyzing the reasonableness element of a rule of reason claim. If firms could be confident that the competitive effects of their agreements would always be quickly, cheaply and accurately determined in litigation, they would engage in efficient, lawful agreements and avoid inefficient, unlawful agreements. However, the prospect of litigation can cause firms to avoid agreements that might be erroneously condemned, either by erroneous judgments or settlements. This deprives the economy of the benefits of the efficient agreements. ${ }^{99}$ It is important to recognize that the loss of efficient agreements occurs even though the firms might never have been sued for their participation in the agreements, and even if they had been sued, a false positive would not have occurred. Over-deterrence due to potential false positives thus affects all firms con-

96 See William H. Page, The Scope of Liability for Antitrust Violations, 37 STAN. L. REv. 1445, 1452-53 (1985).

9715 U.S.C. $\S 1$ (2006).

98 See, e.g., Texaco Inc. v. Dagher, 547 U.S. 1 (2006).

99 It also undermines firms' incentives to refrain from engaging in inefficient, unlawful agreements because both good and bad agreements are equally impacted if litigation does not predictably condemn only wrongful conduct. 
templating agreements, along with all economic activity that depends on their conduct.

The costs to the economy caused by false positive error involving the agreement element of Sherman Act $\S 1$ claims are less obvious. A false positive involving the agreement element would occur when a judgment or settlement for the plaintiff occurs even in the absence of an agreement. This is the false positive that concerned the Court in Twombly. Had the litigation in Twombly proceeded past the complaint stage, the defendants might have been tempted to settle even if they had not actually entered into an agreement dividing the nation into noncompetitive territories in violation of the per se rule against horizontal market allocation. ${ }^{100}$

How would such a false positive over-deter lawful, unilateral behavior? One paradox of Twombly is that the Court failed to identify exactly what behavior firms in a situation similar to the defendants would avoid due to a fear of litigation. Such firms might avoid any contact with competitors out of a fear that they will be erroneously determined to be in an agreement. It is possible that such contact would create pro-competitive effects if it had occurred. It is also possible that firms will avoid entering into pro-competitive agreements out of a fear that they will be erroneously accused or found to have entered into additional anticompetitive agreements. ${ }^{101}$

False positive error can also occur in the context of $\S 2$ of the Sherman Act, which prohibits monopolization. ${ }^{102}$ A monopolization offense has two elements: (1) the possession of monopoly power and (2) the acquisition or maintenance of that power by unlawful conduct. An erroneous judgment or settlement for the plaintiff may occur if the defendant did not possess monopoly power or had not engaged in conduct giving rise to liability under $\S 2$. The cost of over-deterrence is especially obvious in the context of the conduct element. Firms that possess monopoly power must regularly make decisions that could negatively affect their competitors. Fear of litigation may cause a monopolist to keep prices high, reduce production, and avoid efficiently bundling its products or efficient exclusive arrangements with its customers or suppliers. Such over-deterrence may prevent monopolists from operating efficiently. Thus, litigation can over-deter efficient behavior both in the context of $\S 1$ and $\S 2$ causes of action. Over-deterrence affects firms that might never have been sued had they engaged in the deterred behavior.

100 See supra text accompanying notes 38-43.

101 Cf. Starr v. Sony BMG Music Entertainment, 592 F.3d 318, 319 (2d Cir. 2010) (noting plaintiff's claim that conceded joint-venture agreement was the basis for a secret and unlawful price-fixing agreement).

102 See infra text accompanying notes 155-57. 
The cost to society of false positive error is also high in the civil rights context - as demonstrated by the claim addressed in Iqbal. In order to overcome a defendant's assertion of qualified immunity, a plaintiff in a Bivens action must establish that the defendants violated a clearly established right. ${ }^{103}$ Even that stringent standard will produce false positive error if a plaintiff collects an erroneous judgment or non-merit-based settlement.

Governmental officials, sometimes even at the highest levels, such as the defendants Ashcroft and Mueller in Iqbal, concerned about litigation might avoid lawful conduct in the pursuit of a governmental interest. Avoidance of lawful conduct by governmental officials does not merely reduce the efficient functioning of private markets, it also impairs the effective pursuit of society's noneconomic interests. Iqbal itself addresses a dramatic example of that potential problem. The defendants in Iqbal were senior officials responding to a coordinated multi-pronged attack that killed thousands of people. They were trying to prevent further attacks. Society has a strong interest in preventing such attacks via lawful policies. If policies that could be lawful and effective are deterred by fear of litigation, society's interests are impaired.

\section{Determining the Expected Cost of False Positive Errors}

Merely concluding that false positive error in a particular area of law is costly when it occurs, as it is in antitrust claims and in the civil rights claim at issue in Iqbal, does not mean that such error results in a significant detriment to society. Such detriment occurs only if error is particularly likely. It is only when false positive error is both costly and likely that it produces a significant social detriment. We define that circumstance to be one in which there is a high expected cost of false positive error. ${ }^{104}$

False positives occur in at least three ways. First, a trier of fact may erroneously conclude that the elements of a cause of action are met. Second, a defendant facing a nonmeritorious claim may settle rather than face the chance of an erroneous judgment, or especially burdensome discovery. Third, an actor may avoid certain conduct altogether because of the danger of litigation. The likelihood that all three false positives will occur varies depending on the nature of the facts in controversy. Further, the nature of the facts in controversy varies with each element of the substantive law involved.

103 Ashcroft v. Iqbal, 129 S. Ct. 1937, 1948-49 (2009).

104 Cf. Robert G. Bone, Twombly, Pleading Rules, and the Regulation of Court Access, 94 Iowa L. REv. 873, 911 \& n.169 (2009) (noting that false positive error is one component of expected error cost). Bone's broader expected error-cost framework does not accommodate the Iqbal and Twombly Courts' narrow focus on false positive error. 


\section{The Likelihood of False Positive Error is Greater If Discovery Will Be Especially Burdensome}

Some factual questions relate to facts that are known to more than one person, while others relate to facts directly known only to one person. In a simple negligence claim arising from a car accident, for example, more than one person knows some of the relevant facts. Both the plaintiff and the defendant know the time, date, and location of the accident. Each party knows the condition of the roadway, the weather at the time of the accident, what it observed about each car's speed, direction of travel prior to the accident, and the apparent condition of all parties after the accident. Third-party witnesses may have also observed some of those facts. But even in a simple car accident, some relevant facts are known only to one person. The extent of pain suffered by the plaintiff is directly known only to the plaintiff. Similarly, only the plaintiff knows whether the pain has subsided over time. Only the plaintiff knows the extent to which the pain impairs his or her ability to work. ${ }^{105}$ Similarly, only defendants know whether they saw the plaintiff's car prior to colliding with it, and only defendants know whether they took their eyes off the road immediately prior to the accident.

Whether more than one person knows facts affects the likelihood of false positive error. If only one person knows facts, then the likelihood that the trier of fact will commit an error increases. The trier of fact has only one direct source of information about the relevant fact, and that source may be a party with an incentive to avoid revealing the fact. Alternatively, the source of the information may appear biased and therefore may be tainted in the eyes of the trier of fact. In such a situation, the trier of fact may reach an erroneous conclusion about the fact resulting in a false positive or a false negative. The possibility of an erroneous conclusion by the trier of fact may also induce the parties to settle. The settlement may result in a false positive or a false negative. Moreover, concern about error in litigation may impact the parties' conduct outside the litigation setting. In the car accident example, driving is disincentivized for the would-be defendants.

Whether facts are known to more than one person may also affect the likelihood of error by affecting the extent and nature of discovery. If facts are known to both parties, then discovery is not likely to be especially burdensome. In the car accident example, both parties know the location of the accident. The location of the accident will determine the applicable speed limit. No extensive discovery will be required to allow

105 Facts known only to the plaintiff increase the plaintiff's litigation costs vis-à-vis the defendant. Stancil, supra note 93, at 126. Facts of that sort will increase the risk of false negative error. See supra note 94. 
plaintiffs to prove that fact because they may testify to it. ${ }^{106}$ In contrast, plaintiffs probably have no direct knowledge about whether defendants adequately maintained their car prior to the accident. Depositions and document production may be appropriate to collect evidence about that potentially relevant fact. In more complex cases, there may be differences in the extent of discovery that is appropriate depending on who has direct access to relevant facts.

This produces a paradox that the Supreme Court neither recognized nor resolved in Iqbal and Twombly. The less public the fact, the more burdensome the discovery required to prove it. Therefore, under Iqbal and Twombly, a court's initial inquiry into the complaint should be more searching. But because the fact is nonpublic, it is less likely the plaintiff would be able to allege it in the complaint. ${ }^{107}$

In Twombly, the plaintiffs' horizontal market allocation claim hinged on whether employees of the largest telecommunications companies in the nation had entered into an express agreement to divide territories. ${ }^{108}$ The plaintiffs had no direct knowledge of the existence of such an agreement. ${ }^{109}$ If the complaint had survived the motion to dismiss, plaintiffs could have conducted discovery to find evidence of that agreement to present at trial. That discovery could have been very burdensome. Since the corporate defendants would have been liable for agreements entered into by their employees, a large number of employees could have been deposed to determine if they had entered into any of the forbidden agreements. ${ }^{110}$ In advance of those depositions, document and electronic discovery regarding the travel and telephone records, and paper and email correspondence, could have been appropriate. Determining whether any of a large number of employees of one defendant communicated with any of a large number of employees at any of several other defendants' offices is a daunting task.

106 Cf. Stancil, supra note 93, at 129-30 (risk of "cost arbitrage suits"-in which a rational plaintiff will file a truly frivolous claim-increases with increases in the defendant's internal pretrial costs); $i d$. at 133 ("[T]here is a real risk of frivolous suit in the perfect storm ... [w] hen cost disparity significantly favors the plaintiff.").

107 See Stancil, supra note 93, at 133 ("This correlation presents a conundrum: the cases in which a stricter pleading standard is most justified on Type I error grounds are precisely the cases in which a more liberal pleading standard is most justified on Type II error grounds.").

108 See Twombly v. Bell Atlantic Corp., 313 F. Supp. 2d 174, 179 (S.D.N.Y. 2003) ("[A]bsent an agreement among competitors to restrain trade, anti-competitive behavior does not violate $\S 1 . ”)$.

109 Amended Complaint para. 51, Twombly, 550 U.S. 544 (2007) (No. 02 CIV. 10220), 2003 WL 25629874 (alleging conspiracy “on information and belief”); id. paras. 37-50 (alleging circumstantial facts supporting the ultimate allegation of conspiracy).

110 The complexity of the concept of agreement also threatens further to complicate discovery on that element, as it is difficult to know in advance what conduct is relevant to proving agreement. See supra note 48; see also Huffman, The Necessity of Pleading Elements in Private Antitrust Conspiracy Claims, supra note 7, at 645-57. 
Iqbal involves another situation where the plaintiffs had no direct knowledge of a relevant fact. The plaintiff in Iqbal had no direct knowledge about whether Attorney General Ashcroft and Director Mueller possessed the required discriminatory intent. Unlike Twombly, however, there were not a large number of employees of a corporate defendant who might have direct knowledge of the contested facts. In Iqbal, unlike Twombly, the doctrine of respondeat superior did not apply. ${ }^{111}$ Therefore, only Ashcroft and Mueller knew whether they possessed the prohibited discriminatory intent.

Like the plaintiff in Twombly, the plaintiff in Iqbal could not establish the contested fact based on his own testimony. Discovery related to discriminatory intent by Ashcroft and Mueller would not be limited solely to their own depositions. The plaintiff would likely also want to review paper and electronic correspondence connected to Ashcroft and Mueller. Further, there were a number of subordinate governmental officials who were defendants in the case. ${ }^{112}$ It is possible that those defendants, and other governmental officials who might be deposed as witnesses, would testify that Ashcroft and/or Mueller knew of and agreed with their actions. Counsel for Ashcroft and Mueller would want to participate in discovery to monitor that possibility. Although the extent of discovery relevant to possible discriminatory intent by Ashcroft and Mueller would probably be less extensive than that related to the possible anticompetitive agreement in Twombly, it would still be burdensome. ${ }^{113}$

The prospect of burdensome discovery increases the likelihood of false positive error. When discovery is likely to be especially burdensome for the defendant, the incentive for the defendant to settle increases. That is so even if fully litigating the case would result in a judgment for the defendant. Even defendants who can confidently predict that they will win the case at trial have an increased incentive to settle if discovery promises to be especially burdensome. That increased incentive to settle, which is caused by the prospect of burdensome discovery, increases the likelihood of false positive error.

\section{E. The Plausibility Standard Turns on the Expected Cost of False Positive Error}

The plausibility standard developed in Twombly and Iqbal is intended to avoid false positive error. Its application therefore must vary depending on the expected cost associated with false positives on the

111 See supra text accompanying note 57.

112 See Elmaghraby v. Ashcroft, 2005 WL 2357202, at *1 (E.D.N.Y. Sept. 27, 2005) (listing defendants).

113 Iqbal superbly demonstrates the Twombly paradox: the less publicly available the fact, the more specifically plaintiffs will be required to allege it. 
particular element of the claim in issue. The first factor in the expected cost of false positives calculus is whether the substantive area of law involved is one where error is costly if it occurs. That will depend on whether false positives will over-deter especially important, beneficial behavior.

The second factor in the expected cost calculus is whether error is especially likely. That will depend on whether discovery will be especially burdensome, which in turn depends on whether the contested facts are public, quasi-public, or known only to the defendant. In turn, that will vary depending on which element of which claim is in controversy. ${ }^{114}$ In a single claim, different elements might give rise to different types of contested facts. Therefore, the likelihood of false positives will be a function of which element is in controversy. The pleading standard must vary, element-by-element, depending on the type of facts relevant to making proof of each element. ${ }^{115}$

The strongest case for a high plausibility standard exists where the expected cost of false positive error is great. This is so when false positive error is both likely and costly. This was the case in both Twombly and Iqbal. As discussed above, both cases involve substantive areas of law where false positives are costly if they occur. Also, the element raising the pleading question in each case related to facts uniquely in the hands of the defendants - the agreement issue in Twombly and the discriminatory intent issue in Iqbal. Each of those factual issues raised the prospect of burdensome discovery, making false positives especially likely.

Since both cases addressed situations where false positives are both costly and likely, the Supreme Court has not faced a situation where one or both of those variables has been different. If either the cost or likelihood of a false positive is low, the high plausibility standard applied in Twombly and Iqbal is not justified. Each element of each claim in each area of substantive law needs to be examined to assess whether the high plausibility standard applied in Twombly and Iqbal is justified. ${ }^{116}$ Anti-

114 "[S] everal claim types" are characterized by disparities in costs for plaintiffs and defendants because "the range of permissible inquiry into defendant's affairs increases as pleading specificity requirements decreases, especially for claims in which the plaintiff's own conduct is of little moment." Stancil, supra note 93, at 116.

115 See supra notes 30-34 and accompanying text (discussing the lesson from Dura Pharmaceuticals that pleading is driven by the substantive elements of the claim).

116 We argue that the treatment of allegations at the motion to dismiss stage depends on the expected cost of false positive error in litigation. The impact of that rule, this Part demonstrates, is disparate treatment of different elements of different claims, seemingly violating the Rule 8 pleading standard's trans-substantivity, which is implicit in the Leatherman rule. See supra notes 21-28 and accompanying text. Judge Posner implicitly approved that reality:

The [Twombly] Court held that in complex litigation (the case itself was an antitrust suit) the defendant is not to be put to the cost of pretrial discovery - a cost that in 
trust law provides an important context for applying the plausibility standard. It is an area of law where false positives, if they occur, are costly. In antitrust law, a plaintiff may make several types of claims, each of which have several elements and raise different types of factual questions. An analysis of antitrust law demonstrates how substantive law interacts with the rationale for the plausibility standard in such a manner as to raise pleading standards of different heights consistent with the rationale of mitigating expected costs of false positive error.

\section{Applying the Twombly/Igbal Framework to Antitrust Claims}

In this Part we consider the elements of individual antitrust claims within the framework developed in Part II. That consideration enables us to determine the appropriate application of Rule 8 to each claim.

The Sherman Act has two principal sections, section one ${ }^{117}$ and section two. ${ }^{118}$ Each of those sections has two elements. The first element of a claim under $\S 1$ is the existence of an agreement between two or more actors. ${ }^{119}$ The second element of a claim under $\S 1$ is that the agreement must be in "unreasonable" restraint of trade. ${ }^{120}$

The first element of a monopolization claim under $\S 2$ is that the defendant has monopoly power. ${ }^{121}$ The second element requires that the defendant acquire or preserve its monopoly power with prohibited conduct. ${ }^{122}$ A two-section statute giving rise to two discrete claims, each of which has two elements, might seem simple to apply. However, over 120 years, courts, litigants, and commentators have discovered that those

\footnotetext{
complex litigation is so steep as to coerce a settlement on terms favorable to the plaintiff even when his claim is very weak - unless the complaint says enough about the case to permit an inference that it may well have real merit. The present case, however, is not complex. . . Iq Iqal is special in its own way, because the defendants had pleaded a defense of official immunity and the Court said that the promise of minimally intrusive discovery "provides especially cold comfort in this pleading context."
}

Smith v. Duffey, 576 F.3d 336, 340 (7th Cir. 2009). Judge Posner makes the point that the scope of review of a plaintiff's allegations turns not on some labeling of claims, but on the realities of false positive error with regard to certain kinds of claims. It is thus possible, as we have shown above, that a rule uniformly applied across different claims, even within a particular area of law, will mandate disparate treatment of those claims.

11715 U.S.C. $\S 1$ (2006).

11815 U.S.C. $§ 2$ (2006).

119 The agreement element arises from Section One's requirement of a "contract, combination . . or conspiracy." 15 U.S.C. $\S 1$. This was the element in controversy in Twombly. See supra text accompanying notes 37-49.

120 See infra text accompanying notes $145-49$.

121 See infra text accompanying notes 154-62. The statement in the text applies to a claim of actual monopolization. Section Two also prohibits attempted monopolization and conspiracies to monopolize.

122 See infra text accompanying notes 163-65. 
four elements - individually and in combination - create a massively complex body of law. The complexity of the substantive law makes analyzing the pleading standard applicable to each element commensurately complex.

Part II of this Article articulated the framework for applying the Twombly/Iqbal standard to antitrust claims. It demonstrates that one part of the expected-cost inquiry-the cost of false positives where they occur-is high for antitrust claims, although there are differences among claims depending on the particular conduct at issue. In this Part we analyze the individual elements of the primary antitrust claims-both per se and rule of reason claims under Sherman Act $\S 1$ and monopolization claims under Sherman Act $\S 2$ - under the expected-cost inquiry from Part II. We then go on in Part IV to analyze cases decided since Twombly, and the relatively few cases decided since Iqbal, to determine their fidelity to the correct rule. ${ }^{123}$

\section{A. Conspiracies Restraining Trade}

\section{Agreement}

A single actor cannot unilaterally violate $\S 1$ of the Sherman Act. ${ }^{124}$ Section One requires an agreement between two separate actors. ${ }^{125}$ Whether such an agreement exists raises both factual and legal issues, which have different impacts depending on whether the agreement is to be proved directly or circumstantially. Factual issues include such basic questions as who talked to whom, when the parties talked, where they talked, and what they said. In Twombly, for example, it would be important to know whether the chief executive officer of one defendant telephone company telephoned the chief executive officer of another defendant telephone company. If such a telephone call occurred-with the executives agreeing that the corporations would stay out of each

123 We do not examine other antitrust claims, including merger challenges under Clayton Act Section Seven and secondary-line price discrimination claims under the Robinson-Patman Act. The former comprise a small portion of federal courts' antitrust dockets and are even more rarely the subject of private litigation. But see Paul Stancil, Atomism and the Private Merger Challenge, 78 TemP. L. Rev. 949 (2005). The latter are disfavored under most modern antitrust analyses.

124 Monsanto Co. v. Spray-Rite Service Corp., 465 U.S. 752, 761 (1984) ("There is the basic distinction between concerted and independent action-a distinction not always clearly drawn by parties and courts. Section 1 of the Sherman Act requires that there be a "contract, combination ... or conspiracy" between the manufacturer and other distributors in order to establish a violation. Independent action is not proscribed.").

125 Persons within a single firm are deemed to be part of one actor for purposes of that requirement. See Copperweld Corp. v. Independence Tube Corp., 467 U.S. 752 (1984) (holding that a parent and a subsidiary corporation cannot conspire within the meaning of $\S 1$ ). 
other's territories - the call would constitute direct proof of an illegal agreement under $\S 1 .{ }^{126}$

Even if the facts of an antitrust case are undisputed, whether those facts add up to an agreement cognizable under the agreement element of $\S 1$ raise conceptually complex legal questions. The legal issues are simple at the margins. If two parties expressly communicate, whether orally or in writing, and agree about what one or both of them will do, the communicated agreement will satisfy the first element of $\S 1 .{ }^{127}$ Similarly easy is a case where two parties do not communicate with each other and engage in independent conduct. Conduct is independent when it is profit-maximizing for one party regardless of the conduct of another party. ${ }^{128}$ Such purely independent conduct does not constitute an agreement for the purposes of $\S 1 .{ }^{129}$ A difficult conceptual question is whether conduct which is neither the product of an express communicated agreement, nor independent, constitutes an agreement for the purposes of $\S 1$.

Conduct by two parties is interdependent when its profit-maximizing nature for each party depends on the conduct of the other. When two parties are competitors, they might act like cartelists without ever communicating with each other and expressly agreeing. They might raise prices above the competitive level or stay out of each other's territories by virtue of their recognition that it is in their collective interest to do so. In such a case, economists recognize the harm to competition would be similar to that created by a communicated agreement. However, in such a case no communicated agreement would be present. In Twombly, the Supreme Court stated that such "mere interdependence" would not be sufficient to establish an agreement under $\S 1$, explaining that "[e]ven 'conscious parallelism,' a common reaction of 'firms in a concentrated market [that] recogniz[e] their shared economic interests and their interdependence with respect to price and output decisions' is 'not in itself

126 See supra note 39. Such an overt agreement may be investigated and prosecuted criminally. See 15 U.S.C. $\S 1$ (2006) (stating that an agreement to restrain trade is a "felony" carrying lengthy prison sentences and fines).

127 Such an agreement would, of course, be lawful under $\S 1$ if it did not unreasonably restrain trade. See Chicago Bd. of Trade v. United States, 246 U.S. 231 (1918).

128 Cf. E. Thomas Sullivan \& Herbert Hovenkamp, Antitrust Law, Policy \& ProCedure: Case and Materials 187 (5th ed. 2003).

129 See, e.g., Theatre Enters., Inc. v. Paramount Film Distrib. Corp., 346 U.S. 537, 540-42 (1954). 
unlawful." "130 Thus, in pleading and proving an agreement under $\S 1$, the plaintiff must establish a communicated agreement. ${ }^{131}$

In many cases, if an agreement is established, the plaintiff wins. This is so because some agreements are deemed to be unreasonable per se. Because there is no factual inquiry into the competitive effects of the agreement in per se cases, the entire case turns on the agreement element. "The per se rule, treating categories of restraints as necessarily illegal, eliminates the need to study the reasonableness of an individual restraint in light of the real market forces at work. ..."132 Twombly reiterates that a per se claim is functionally a single-element claim. Successfully pleading and proving the agreement element subjects the defendant to automatic liability. The second element-reasonableness of the restraint-is foreordained as a matter of law. ${ }^{133}$

The error cost of a false positive in a per se claim is high. An erroneous finding of an agreement can subject the defendant to liability for socially beneficial conduct. If threatened with antitrust liability, a firm might be disinclined to attend trade shows, where engineering and marketing improvements-including cost savings, which in a competi-

130 Twombly, 550 U.S. 544, 553-54 (2007) (citing Brooke Group Ltd. v. Brown \& Williamson Tobacco Corp., 509 U.S. 209, 227 (1993)); Areeda \& Hovenkamp supra note 79 II 1433a, (2d ed. 2003) ("The courts are nearly unanimous in saying that mere interdependent parallelism does not establish the contract, combination, or conspiracy required by Sherman Act $\S 1$ ”); Turner, supra note 48, at 672 ("[M]ere interdependence of basic price decisions is not conspiracy").

131 See William H. Page, Communication and Concerted Action, 38 Loy. U. CHI. L.J.. 101, 101 (2007) (defining agreement by reference to the existence of actual communication between the parties). Professor Page applied his test post-Twombly, reading cases reviewing the agreement element as turning on whether the plaintiff has alleged "communication" among the defendants. William H. Page, Twombly and Communication: The Emerging Definition of Concerted Action Under the New Pleading Standards, 5 J. Competition L. \& Econ. 439, 459-64 (2009) [hereinafter Page, Twombly and Communication]. Page's thoughtful analysis holds in many post-Twombly cases analyzing allegations of agreement. See id. at 455-64. That is consistent with our argument that a plaintiff seeking to prove conspiracy directly will be required to plead with greater specificity because of the burden of discovery. See infra notes $136-38$ and accompanying text.

132 Leegin Creative Leather Prods., Inc. v. PSKS, Inc., 551 U.S. 877, 886-87 (2007). A per se rule reaches a generally applicable conclusion about the economic effect of a category of behavior. Per se rules thus require courts to make broad generalizations about the social utility of particular commercial practices. The probability that anticompetitive consequences will result from a practice and the severity of those consequences must be balanced against the practice's pro-competitive consequences. Cases that do not fit the generalization may arise, but a per se rule reflects the judgment that such cases are not sufficiently common or important to justify the time and expense necessary to identify them. See Continental T. V., Inc. v. GTE Sylvania Inc., 433 U.S. 36, 50 n.16 (1977).

133 To be sure, legal arguments remain on whether particular conduct is, or is not, sufficiently anticompetitive to warrant per se treatment. However, those arguments do not implicate the pleading analysis. 
tive marketplace inure to consumers' benefit-may be discussed. ${ }^{134}$ The firm might be disinclined to imitate product improvements implemented by competitors, for fear of appearing to engage in parallel conduct. The firm might be disinclined to match price reductions implemented by competitors for the same reason. ${ }^{135}$ The harm caused by disincentivizing such potentially beneficial business conduct is antithetical to the antitrust laws' purpose of enhancing competition for the benefit of consumers.

The expected cost of false positive errors analysis next requires an assessment of the likelihood of a false positive. The likelihood of a false determination of liability (or settlement) on the agreement element of a $\S 1$ claim depends on the manner in which the agreement is to be pleaded and proved. A plaintiff can prove a conspiracy with direct evidence. The Third Circuit, in Cosmetic Gallery, Inc. v. Schoeneman Corp., defined direct evidence as evidence that "evince[s] with clarity a concert of illegal action." 136 The Third Circuit listed several examples, including (1) a direct threat by one competitor to the plaintiff that competitors would prevent plaintiff's success; (2) a threat that a supplier would cut off access if the distributor failed to maintain prices; (3) a memorandum detailing the discussions of a group of conspirators; and (4) a public resolution by conspirators. ${ }^{137}$

If a plaintiff relies on direct evidence of an agreement, it is relatively simple to assess the pleadings and weigh the evidence. However, the evidence on which the plaintiff will rely is uniquely in the hands of the defendant. Unless the fact of an agreement was communicated to the plaintiff or third parties - which is unlikely given the criminal liability that attaches to per se violations of $\S 1$ 138_discovery targeting direct evidence of an agreement requires depositions and document discovery of the defendant. Where the defendant is an organization, in which multiple-perhaps hundreds or thousands of-individual agents are authorized to act on its behalf, the scope of such discovery threatens to be massive.

Finally, such discovery is entirely one-sided. Nothing about the single contested element of a per se claim requires discovery from the plaintiff. Such one-sided discovery presents a moral hazard problem. If the

$134 C f$. Maple Flooring Mfrs. Ass'n v. United States, 268 U.S. 563 (1925) (industry group discussed costs of shipping product).

135 The error cost is amplified in the case of the per se rule because triers of fact do not have the power to mitigate the harsh result of liability by declaring the conduct engaged in to be "reasonable." If the agreement element is met, liability is automatic.

136 Cosmetic Gallery, Inc. v. Schoeneman Corp., 495 F.3d 46, 52 (3d Cir. 2007).

137 Id. (citing cases). Cosmetic Gallery, which was decided on summary judgment, held that the evidence was not sufficient directly to demonstrate a conspiracy. Id. at 53.

138 See 15 U.S.C. $\S 1$ (2006) (stating that violation is a felony punishable by up to ten years in jail and $\$ 100,000,000$ in fines). 
chances of a lucrative settlement are enhanced by burdensome discovery of the defendant, and if there is no concern for tit-for-tat discovery, the plaintiff is incentivized to make its discovery requests as burdensome as possible. For an allegation that the defendants, or their agents, met and agreed, the threatened burden of discovery, and therefore the likelihood of a false positive settlement, is high. ${ }^{139}$ Twombly dealt with that precise circumstance. The Twombly Court held that the threatened burden of discovery warranted a searching analysis of the complaint. ${ }^{140}$

Circumstantial allegations of agreement present precisely the reverse situation. As a matter of substantive law, a plaintiff relying on circumstantial evidence should succeed in proving the agreement element only if it can prove the observed conduct - usually parallel behavior, which, as Twombly held, is innocent-would not have occurred but for an agreement. ${ }^{141}$ If there is an equally plausible nonconspiratorial explanation for the observed conduct, circumstantial proof will be insufficient. ${ }^{142}$ Exactly what observed conduct meets that standard is a complex question best answered by those trained in economics, based on observations of marketplace conduct that occurs in the public eye.

Although the legal analysis and its factual predicates are detailed, complex, and commensurately expensive to undertake (requiring, at a minimum, the parties retain economic experts), the burden on the defendant of discovery relating to its own conduct in a circumstantial evidence case is low. The discovery burdens are not borne uniquely by the defendant because the facts relevant to proving an agreement by circumstantial evidence are as likely to be available from third parties throughout the market as from the defendant. Many relevant facts-for example, industry pricing trends ${ }^{143}$ or product changes and marketing practices-will be publicly available without resort to the discovery process. The discovery undertaken involves depositions of the other party's expert witnesses, a burden borne equally by the plaintiff and the defendant. The moral hazard created by asymmetric discovery expenses is not present in circum-

139 Of course, it remains possible that the plaintiff could simply make up a fact, rendering even direct allegations of agreement unreliable. Any such activity is the subject of Federal Rule of Civil Procedure 11. See Fed. R. Civ. P. 11.

140 See Bell Atlantic Corp. v. Twombly, 550 U.S. 544, 559 (2007).

141 See E. Thomas Sullivan, Herbert Hovenkamp, \& Howard A. Shelanski, Antitrust Law, Policy \& Procedure 264 (6th ed. 2009) (describing circumstantial proof of agreement by reference to a "but for" allegation); see, e.g., Twombly, 550 U.S. 544, 557 n.4 (discussing a historically unprecedented pattern of parallel pricing behavior).

142 We discuss here the standard for proving an agreement on the basis of circumstantial evidence.

143 See Twombly, 550 U.S. at 557 n. 4 (noting that historical pricing patterns can be a "plus factor" nudging innocent parallel conduct over the line to impermissible conspiratorial conduct). 
stantial evidence cases. For that reason, there is a reduced concern for false positives in circumstantial evidence cases.

We have, then, with regard to per se claims, a dichotomous result. Where agreement is to be proved by direct evidence, the expected cost of the false positive error is high-it is costly if it occurs, and it is likely to occur. The importance of avoiding that cost is commensurately high, so the specificity required of plaintiffs in pleading agreements by direct evidence is high. That is precisely the conclusion the Supreme Court reached in Twombly. Where agreement is to be proved by circumstantial evidence, the expected cost of the false positive error is moderate. It is costly if it occurs, but it is unlikely to occur. Iqbal and Twombly are properly read to teach that where proof is to be made by circumstantial evidence, allegations of agreement may be pleaded with less specificity than those to be proved by direct evidence. ${ }^{144}$

This dichotomy produces a surprising result. In order to properly evaluate a complaint alleging an agreement in violation of $\S 1$ under the rules announced in Iqbal and Twombly, a court must know whether the plaintiff's proof will be direct or circumstantial. If the proof will be direct, the plaintiff must create a sufficient plausible inference that an agreement exists, based on observed facts, that the court will be willing to subject the defendant to burdensome, one-sided discovery requests. The plausibility rule mitigates the false positive concern by increasing the likelihood that the defendant actually engaged in prohibited conduct. But if the proof of agreement will be circumstantial, the two-sided and less burdensome nature of discovery reduces the expected cost of false positive error. Thus, the need for specificity in the complaint is reduced. It would therefore be understandable if courts required plaintiffs to commit, when opposing a motion to dismiss, to one approach or another in proving agreement. ${ }^{145}$

\section{Reasonableness}

Only agreements that "unreasonably" restrain trade violate $\S 1 .{ }^{146}$ Agreements not held to be per se illegal are judged under some form of the "rule of reason." Sometimes the rule of reason is applied by thoroughly analyzing the pro-competitive and anticompetitive effects of an agreement. In other cases, the rule of reason is applied in a truncated fashion, sometimes referred to as a "quick look" rule of reason. Like a

144 It is in this circumstance that the purest form of the "notice" pleading standard should be applied.

145 This approach would be consistent with a district court's power to control discovery and to permit only discovery likely to lead to the discovery of admissible evidence. See FED. R. Crv. P. 26(b)(1).

146 Bd. of Trade of Chicago v. United States, 246 U.S. 231, 238-39 (1918). 
per se claim, a rule of reason claim often centers on only one element. That is because, for a rule of reason claim, the fact of an agreement is usually publicly known, so it is easy to plead and is not the subject of argument on a motion to dismiss. The contested element for the rule of reason claim is usually the effect of the agreement. As it does elsewhere, the Twombly/Iqbal expected cost of false positive error governs the pleading requirement.

The Supreme Court has not been clear about how the rule of reason should be applied. The rule is often phrased as an open-ended inquiry into the reasonableness of the restraint on competition imposed by the agreement. In Continental T.V., Inc. v. GTE Sylvania Inc., the Supreme Court stated that " $[u]$ nder this rule, the fact-finder weighs all of the circumstances of a case in deciding whether a restrictive practice should be prohibited as imposing an unreasonable restraint on competition." ${ }^{147}$ The Supreme Court supported its statement by quoting one of the original-and most famous-statements of the rule of reason:

The true test of legality is whether the restraint imposed is such as merely regulates and perhaps thereby promotes competition or whether it is such as may suppress or even destroy competition .... The history of the restraint, the evil believed to exist, the reason for adopting the particular remedy, the purpose or end sought to be attained, are all relevant facts. ${ }^{148}$

The rule of reason has evolved into a structure of shifting burdens of proof. That structure improves its predictability. The plaintiff bears the initial burden of establishing that the challenged agreement is likely to have anticompetitive effects. The plaintiff may meet its initial burden in one of two ways. First, the plaintiff may meet its burden by engaging in a full analysis of the effect of the restraint in the market-the so-called "full blown" rule of reason. Second, in cases of inherently suspect restraints, the plaintiff is able to meet its burden on a "quick look" basis without a full analysis of the market. ${ }^{149}$ A full market analysis is com-

147 Continental T. V., Inc. v. GTE Sylvania Inc., 433 U.S. 36, 49 (1977).

148 Id. at 50 n.15.

149 The Supreme Court developed the quick look standard in a series of three cases. In National Society of Professional Engineers v. United States, 435 U.S. 679 (1978), the government sued to void an ethical cannon prohibiting competitive bidding. The Court imposed the burden on the defendant to demonstrate a pro-competitive justification without engaging in a thorough analysis of the effect of the restraint on the market. Id. at 692-93. In National Collegiate Athletic Association v. Board of Regents of University of Oklahoma, the Court held that agreements that on their face restrained output and price were sufficient to establish the likelihood of anticompetitive effects without a thorough market analysis or even a definition of a relevant market or a demonstration of market power. 468 U.S. 85, 104-06 (1984). In F.T.C. v. Indiana Federation of Dentists, the Court imposed on the defendants the burden of establishing a pro-competitive justification without requiring the Federal Trade Commission to es- 
plex and expensive because it requires a definition of the applicable market and an inquiry into how the challenged restraint affects that market. Just as importantly, given the complexity of the analysis, the expense of the analysis and the lack of predictability of the outcome of the analysis, a potential plaintiff may not want to try to make the required showing. Plaintiffs much prefer the lighter initial burden of production that the quick look standard promises.

If the plaintiff makes the initial showing of potential anticompetitive effect, the burden shifts to the defendant to demonstrate that the challenged restraint has offsetting, pro-competitive justifications. If the defendant establishes such pro-competitive justifications, the burden shifts back to the plaintiff to establish that the anticompetitive effects outweigh the pro-competitive justifications. Theoretically, the rule of reason requires a balancing of the anticompetitive effects and pro-competitive effects of the challenged restraint. However, the balancing question never arises if either party fails in its initial burden of production-if the plaintiff cannot demonstrate the required anticompetitive effect or if the defendant fails thereafter to establish a pro-competitive justification. ${ }^{150}$

The likelihood of a false positive on the reasonableness element of a full-blown rule of reason claim is low. As with an agreement to be proved by circumstantial evidence (discussed in the prior section), the high burden and expense of litigating the issues of relevant market, likely anticompetitive effects, and countervailing pro-competitive considerations is a distraction. For purposes of applying the Twombly/Iqbal standard, what is important is that proof of market effects of an agreement generally will be available from sources other than the defendant. The discovery of the defendant that does take place is simpler as well. Unlike the secret agreement in a per se claim, a defendant in a rule of reason case should know which of its agents was involved in the decisions being challenged because those decisions are publicly known. The true expense of litigation is preparing and taking expert testimony. Those costs, however, are borne equally by the plaintiff and by the defendant. No problematic asymmetries exist.

tablish the likelihood of anticompetitive effects by means of a thorough market analysis. 476 U.S. 447, 459 (1986).

150 The leading discussion of the respective burdens of the plaintiff and the defendants in a rule of reason case is found in California Dental Association v. F.T.C., 526 U.S. 756 (1999). California Dental reflects a debate between Justice Souter, writing for a five-justice majority, and Justice Breyer in dissent. The disagreement is about whether the plaintiff in a rule of reason case must, in meeting its initial burden of establishing the likelihood of anticompetitive effects, analyze possible pro-competitive effects of the challenged restraint. Id. at 771-76. The answer to this question affects whether the claim can be analyzed on a quick-look basis. Justice Souter's opinion for the Court holds that the plaintiff must engage in an analysis of possible pro-competitive effects of the agreement in bearing its initial burden of establishing the likelihood of anticompetitive effects. Id. 
When bringing a quick-look claim, the plaintiff is traditionally permitted to rely on an assertion of harm. The defendant is then required to respond with pro-competitive justifications, before the plaintiff bears the ultimate burden of proving that the harm to competition outweighs any possible pro-competitive justifications for the restraint. Unlike with the full-blown rule of reason, the plaintiff's initial burden, traditionally conceived, is merely to demonstrate the existence of a suspect agreement.

The likelihood of a false positive should be the same, whether the claim is a quick-look claim or a full-blown rule of reason claim. This is because questions involved in both quick-look and full-blown rule of reason claims relate to the economic effects of the agreement and do not implicate burdensome discovery. One exception exists: quick-look claims deal with inherently suspect restraints. It is possible that the agreements underlying a quick look analysis took place in secret. The asymmetric discovery burden on the agreement element would apply to such a claim just as it would with a per se claim. ${ }^{151}$

\section{B. Monopolization}

Section Two of the Sherman Act prohibits monopolization. ${ }^{152}$ The monopolization offense has two elements-power and conduct. ${ }^{153}$ Unlike a $\S 1$ claim, circumstances rarely arise in a $\S 2$ claim in which one of the two elements is, for practical purposes, uncontested. ${ }^{154}$ Calculating the expected cost of false positive error on a $\S 2$ claim therefore requires considering both the cost of false positive errors (determined above to be high throughout the body of antitrust law) and the likelihood that each element produces a false positive.

151 See supra notes 135-38 and accompanying text.

152 Only a few cases discuss Twombly in the context of $\S 2$. See, e.g., Port Dock \& Stone Corp. v. Oldcastle Northeast, Inc., 507 F.3d 117 (2d Cir. 2007) (dismissing monopolization claims based on unilateral refusals to deal with competitors and citing Twombly for the standard on a motion to dismiss); Pac. Bell Tel. Co. v. Linkline Commc'ns, Inc., 129 S. Ct. 1109, 1123 (2009) (referencing the necessity that the complaint in that $\S 2$ case meet the Twombly standard on remand).

153 See United States v. Grinnell Corp., 384 U.S. 563, 570-571 (1966) ("The offense of monopoly under $\S 2$ of the Sherman Act has two elements: (1) the possession of monopoly power in the relevant market and (2) the willful acquisition or maintenance of that power as distinguished from growth or development as a consequence of a superior product, business acumen, or historic accident."); see also Verizon Communications Inc. v. Law Offices of Curtis V. Trinko, 540 U.S. 398, 407 (2004); Pacific Bell Telephone Co. v. Linkline Commc'ns, Inc., 129 S.Ct. 1109, 1118 (2009).

154 For example, the Microsoft Corporation, with as much as 95\% market share, nonetheless contested the market power element in a $\S 2$ suit brought by the United States in 1998. See William H. Page \& John E. Lopatka, The Microsoft Case 96-114 (2007). Microsoft was able to raise a difficult legal question on the issues of market definition and entry barriers, two issues inextricable from the larger market power question. See id. Likewise, the conduct element of a $\S 2$ claim will nearly always be contested. 


\section{Market Power}

The market power element of a $\S 2$ claim requires that the defendant possess substantial power over price. ${ }^{155}$ Such power is commonly inferred from the defendant's possession of a high share of an appropriately defined market. ${ }^{156}$ Therefore, market definition plays a crucial role in monopolization cases.

A market is determined by asking what alternatives a purchaser has to satisfy his or her demand if an alleged monopolist raises its price. The most obvious alternative is to purchase exactly the same product from another seller at exactly the same location. Such alternative sellers of the same product in the same geographic location are obviously included in the market. More difficult line-drawing questions arise with respect to other possible alternative suppliers. Should sellers of somewhat different products, at the same location as the defendant, be included in the market? The answer is reached through an economic calculus, called the "cross-elasticity of demand." If the customer views those other products as good substitutes for the product produced by the alleged monopolist, there is high cross-elasticity. The substitutable products should be included in the market because their presence reduces the alleged monopolist's power to control price. ${ }^{157}$ Similarly, if producers of a different product at the same location could easily begin making the product produced by the alleged monopolist, those other potential producers restrain the alleged monopolist's ability to raise prices. Those potential alternative producers should also be included in the market. This economic calculus of likely entry is called the "cross-elasticity of supply." 158 The process of defining a set of products that are good substitutes from either a demand or supply perspective is referred to as "product market definition."

155 United States v. E.I. du Pont de Nemours and Co., 351 U.S. 377, 391 (1956).

156 United States v. Microsoft Corp., 253 F.3d 34, 51 (D.C. Cir. 2001) (“[M]onopoly power may be inferred from a firm's possession of a dominant share of a relevant market that is protected by entry barriers."); United States v. Aluminum Co. of America, 148 F.2d 416, 424 (2d Cir. 1945) ("The percentage we have already mentioned—over ninety—results only if we both include all 'Alcoa's' production and exclude 'secondary'. That percentage is enough to constitute a monopoly .....").

157 E.I. du Pont de Nemours, 351 U.S. at 400; United States v. Visa USA, Inc., 344 F.3d 229, 239 (2d Cir. 2003) (relying on expert testimony about consumer preferences in determining the relevant market).

158 The two forms of cross-elasticity require wholly separate economic analyses. Crosselasticity of supply does not depend on cross elasticity of demand. For example, from a purchaser's viewpoint, auto hubcaps and fenders are poor substitutes for each other. However, if a supplier can easily switch from making hubcaps to fenders, hubcaps and fenders are in the same market. Such markets can be defined based on a process of production rather than on the basis of the end-product produced. For example, hubcaps and fenders may both be produced by firms in the light metal stamping market. 
In addition to defining the product market, a "geographic market" must be defined. This is because producers at other locations may restrain the alleged monopolist's power over price. ${ }^{159}$ In response to a high local price, customers may go to other geographic areas to purchase the product. Those remote producers will therefore have a price-constraining effect on the defendant. Alternatively, producers from distant areas may move to the defendant's location. ${ }^{160}$ They are thus-like the producers of different products who can overhaul production to make the identical product as the defendant-potential competitors. ${ }^{161}$

The task of defining the relevant market, without which market power cannot be proved, is notoriously bound up in factual complexity, including complicated and expensive expert testimony. ${ }^{162}$ Expert opinion may even require statistical support in order for a court to admit it. ${ }^{163}$ Like the reasonableness element of a $\S 1$ claim, the market power element of a $\S 2$ claim may threaten a potential defendant with an expensive investment in expert opinion. But that is a red herring: like the reasonableness element of the $\S 1$ claim, the expense of discovery on the market power element is borne uniformly between the parties. Discovery is not directed uniquely at the defendant in a way that incentivizes the plaintiff to engage in burdensome discovery requests to coerce settlement.

Also, the factual development required for proof of market power often involves facts found in the public domain or maintained by third parties. For example, demonstrating cross-elasticity of supply requires interviewing or deposing third-party competitors or experts in the dy-

159 This applies to producers of identical products, producers of highly substitutable products, and potential producers of identical or highly substitutable products.

160 The customer's ability to purchase at a distance and the sellers' ability to sell in a new area do not depend on each other. Customers may find it difficult to purchase an ice cream cone from a seller located far away. However, sellers of ice cream cones may find it relatively easy to open a store in a new location.

161 See generally Darren Bush \& Salvatore Massa, Rethinking the Potential Competition Doctrine, 2004 Wisc. L. REv. 1035 (analyzing the role of "spectator firms" in affecting competition in a defined market, whether through their eventual entry or through the continual threat of entry).

162 See Keith N. Hylton, Antitrust Law: Economic Theory and Common Law Evolution 230-31 (2003) ("It should come as no surprise that parties spend vast sums of money in litigation in efforts to get the Court to accept their definition of the relevant market."). Professor Hylton notes two other means of measuring market power: profit margins and constraints on pricing. The first is "unsatisfying" because the appropriate measure of profits, economic profit (which is profit net of opportunity cost) "is difficult to measure, and courts typically make feeble efforts at best." Id. at 231. The second alternative approach Hylton describes is little different from measuring market share. Constraints on pricing are precisely the demand and supply cross-elasticities we describe above. And "the key point is that the analysis of pricing constraints is a fact-sensitive, tedious process." Id. at 234 .

163 See William H. Page \& John Lopatka, Economic Authority and the Limits of Expertise in Antitrust Cases, 90 Cornell L. Rev. 617, 660-63 (2005) (citing district court opinions and one opinion by Judge Easterbrook for the Seventh Circuit, excluding testimony for failure to provide statistical analysis support). 
namics of a particular market. Demonstrating cross-elasticity of demand requires interviewing or deposing customers and experts. Market share data is sometimes publicly available. None of that discovery is disproportionately burdensome for the defendant. The likelihood of a false positive occurring on the market power element of a $\S 2$ claim is very low.

\section{Conduct}

A plaintiff's obligation to plead and prove conduct reflects the wellestablished rule that merely acquiring, or possessing, monopoly power is not illegal. ${ }^{164}$ In addition, the defendant must do something to acquire or maintain the monopoly that the law condemns. ${ }^{165}$ The conduct element of the monopolization offense presents some of the most difficult problems raised by antitrust law. ${ }^{166}$ Antitrust law aims to prohibit the acquisition or maintenance of monopoly power by inappropriate means. However, it also wants to encourage vigorous, even cutthroat, competition by all firms including those with monopoly power or with an ability to acquire it. Establishing clear rules to draw the distinction between illegal conduct and vigorous competition - the height of desirable conduct-is difficult. Murky rules addressing that distinction can both erroneously allow inappropriate conduct and erroneously condemn or deter competitive conduct.

The difficulty of the problem is exacerbated by the fact that both illegal monopolizing conduct and legal competitive conduct can injure other firms so much that the injured firms leave the market. In recent decades, the Supreme Court has focused its attention on three areas of the conduct element: predatory pricing, unilateral refusals to deal with competitors, and monopoly leveraging. We apply the Twombly/Iqbal pleading framework to the conduct element of $\S 2$ by also focusing on those three areas of conduct.

164 See Pac. Bell Tel. Co. v. Linkline Commc'ns, Inc., 129 S. Ct. 1109, 1118 (2009); Verizon Commc'ns Inc. v. Law Offices of Curtis V. Trinko, 540 U.S. 398, 407 (2004). This is because monopoly power can be achieved through superior efficiency, reflected in charging lower prices to customers and providing a superior product or service. Antitrust law does not condemn succeeding by being a more efficient competitor. But see United States v. Aluminum Co. of Am., 148 F.2d 416 (2d Cir. 1945).

165 United States v. Grinnell Corp., 384 U.S. 563, 570-71 (1966).

166 In 2006 and 2007 the United States Department of Justice and the Federal Trade Commission held a year-long series of hearings to inquire into the conduct element of the monopolization offense. In September 2008 the Department of Justice issued a report stating its view regarding the conduct element. Despite its co-sponsorship of the hearings, the Federal Trade Commission declined to join in the report. In May of 2009, following a change in administrations, the Department of Justice expressly withdrew the report stating its disagreement with the 2008 report's conclusions. This series of events reflects the division of opinion regarding the conduct element. 


\section{a. Predatory Pricing}

A monopolist reaps the benefits of a monopoly position by pricing high and cutting output. ${ }^{167}$ High prices injure purchasers but they do not exclude rival firms. Indeed, it is a tenet of neoclassical economic theory that high pricing by a monopolist encourages entry and expansion by rival firms. ${ }^{168}$ This entry and expansion, whether it actually occurs or is threatened, can reduce or eliminate the power of the monopolist.

Low pricing by a monopolist, on the other hand, can exclude rivals. ${ }^{169}$ However, courts are hesitant to condemn low prices, which benefit customers and move prices closer to those that would prevail in a competitive market, a price-point that represents the antitrust ideal. ${ }^{170}$ The Supreme Court addressed that conundrum in Brooke Group Ltd. v. Brown \& Williamson Tobacco Corp. ${ }^{171}$ by creating a two-part test to determine whether pricing by a monopolist represents illegal conduct meeting the second element of $\S 2$. Pricing is predatory, and therefore impermissible, if (1) it is below "an appropriate measure of" the monopolist's cost of production, and (2) the monopolist has a dangerous probability of recouping the losses it incurs by raising its prices later. ${ }^{172}$

167 The phrase "high price" actually refers to "quality-adjusted price," such that the high price can be achieved through decreasing the quality of the product or service offered.

168 Either approach to reaping monopoly rents - increasing prices or decreasing qualitywill encourage entry by competitors, who are attracted by the spread between the costs of production and the revenue to be gained from the sale of the product or service.

169 See Richard A. Posner, Antitrust Law 208 (2d ed. 2002) (noting the possibility of successful predatory pricing as an exclusionary strategy). See generally Note: When is Predatory Pricing Rational?, in Sullivan ET AL., supra note 141, at 767-71. We here likewise refer to quality-adjusted price.

170 Barry Wright Corp. v. ITT Grinnell Corp., 724 F.2d 227, 231 (1st Cir. 1983) (“[O]ne must ask why the Sherman Act ever forbids price cutting. After all, lower prices help consumers. The competitive marketplace that the antitrust laws encourage and protect is characterized by firms willing and able to cut prices in order to take customers from their rivals. And, in an economy with a significant number of concentrated industries, price cutting limits the ability of large firms to exercise their 'market power'; at a minimum it likely moves 'concentrated market' prices in the 'right' direction-towards the level they would reach under competitive conditions. Thus, a legal precedent or rule of law that prevents a firm from unilaterally cutting its prices risks interference with one of the Sherman Act's most basic objectives: the low-price levels that one would find in well-functioning, competitive markets." (citations to scholarly authorities omitted)); see also Kartell v. Blue Shield of Mass., Inc., 749 F.2d 922, 931 (1st Cir. 1984) ("[C]ourts . . . should be cautious_reluctant to condemn too speedily_an arrangement that, on its face, appears to bring low-price benefits to the consumer.").

171509 U.S. 209 (1993).

172 Brooke Group Ltd. v. Brown \& Williamson Tobacco Corp., 509 U.S. 209, 222-26 (1993) (applying the test in the context of the price discrimination prohibition contained in Robinson-Patman Act $\S 2(a), 15$ U.S.C. $\S 13(a)$ and stating that the same test applies to actions under Sherman Act $\S 2$.). The Court has never had occasion to decide what measure of cost is "appropriate." See Brooke Group, 509 U.S. at 223 n.1 (parties agreed that average variable cost was the appropriate measure of cost, and Court "decline[d] to resolve" the question). 
The recoupment element of a predatory pricing claim ensures consumers suffer a net detriment from the monopolist's conduct. ${ }^{173}$

Courts and commentators have spilled much ink over the high cost of false positive error on predatory pricing claims. By pricing low and increasing output, the alleged predator serves consumers' interests perfectly. ${ }^{174}$ Only if the defendant is able to (1) succeed in eliminating its rival through the price war and (2) maintain its monopoly position for long enough to recoup the losses incurred by predatory pricing do consumers sustain net harm from the defendant's conduct. The Supreme Court has taken the position that successful predation is highly unlikely, which means consumers receive a net benefit from the unsuccessful effort. ${ }^{175}$ Litigation that deters unsuccessful predation thus harms consumers. Also, nonpredatory competitive conduct - such as cutting prices to compete, to sell off distressed merchandise, or to establish a toe-hold in a new marketplace-presents no chance of consumer harm because the nonpredatory conduct does not threaten to result in recoupment of the defendant's investment and consequent net consumer harm.

To an antitrust plaintiff or court, it may be difficult to distinguish innocent price-cutting conduct from predatory conduct. Even nonpredatory, consumer-friendly pricing strategies may thus threaten the possibility of sanction. Concern for false positive error motivate the substantive law regarding predatory pricing contained in the Brooke Group test. However, the focus of this Article is false positive error flowing from pleading standards.

The likelihood of false positive error on the conduct element of predatory pricing claims caused by the prospect of burdensome discovery turns, as elsewhere, on the expected cost of litigation for the defendant after the pleading stage. We must then ask what the discovery burden is and whether it is likely to fall disproportionately on the defendant. The answer is a mixed bag. The first element of the impermissible predatory pricing conduct inquiry, which asks whether the prices charged are below an appropriate measure of the defendant's costs, requires comparing the prices charged to some calculus of the defendant's costs. Discovering the prices charged is not difficult - that information should be available either in the public domain, through discovery of the defendant's customers, or both. The defendant might, for example, publish

173 The Supreme Court has also applied the Brooke Group test to alleged predatory buying schemes, in which a firm acquires power as a buyer by bidding-up the prices to drive other purchasers from the market. Weyerhaeuser Co. v. Ross-Simmons Hardwood Lumber Co., 549 U.S. 312, 319-20 (2007); Brooke Group, 509 U.S. at 224.

174 Because the predator necessarily has market power, its low-pricing forces all competitors to price low as well. Consumers thus benefit from the low prices whether or not they actually purchase from the defendant.

175 Brooke Group, 509 U.S. at 226-27. 
price lists, and evidence of undisclosed discounting will be available through interviews or depositions of customers. ${ }^{176}$ That discovery does not disproportionately impact the defendant. The same is true of the recoupment element of the claim. The defendant's ability to recoup losses incurred in predation, by pricing at monopoly levels after the victim is driven from the market, is a function of the sustainability of the defendant's resulting monopoly power. Questions of cross-elasticity of supply and demand, which are so readily addressed with publicly-available information on the monopoly power question, are just as readily answered on the recoupment element. ${ }^{177}$

The inquiry into the defendant's cost structure does, however, require onerous and asymmetric discovery of the defendant. Some elements of the defendant's cost structure, such as costs of inputs (including products used in manufacturing or services, such as shipping) and taxes will be readily available to the plaintiff, who is usually the defendant's competitor. Other elements, including labor costs, costs of proprietary technology, and costs of capital, may be known only by the defendant. There are also accounting problems inherent in allocating joint costs incurred by a defendant that operates in many marketplaces to the particular product or service that is the subject of the predatory pricing claim. Discovery is therefore not limited to the production process of a single product, but may require an analysis of the defendant's company-wide costs.

The foregoing paragraph demonstrates that discovery of the defendant's cost structure, which under Brooke Group is essential to a determination of whether the price charged is above or below an "appropriate measure" of the defendant's costs, places a tremendous burden on the defendant. That burden is borne uniquely by the defendant, thus implicating the moral hazard problem by encouraging burdensome discovery requests in the absence of a credible threat of a tit-for-tat response.

Another attribute of discovery on the price element of a predatory pricing claim raises unique concerns. The information necessary for analyzing the defendant's price structure is extraordinarily sensitive. Although protective orders are available in litigation to limit such

176 Some markets are characterized by greater public availability of pricing information than others. See, e.g., United States v. AMR Corp., 335 U.S. 1109 (10th Cir. 2003) (government predatory-conduct suit against American Airlines where prices are published through the Airline Tariff Publishing system).

177 As elsewhere, we ignore the expense of expert testimony and discovery, which is substantial. Because it is not asymmetric in nature, plaintiffs already are incentivized to minimize the burden on the defendant by not going forward with spurious claims. 
information's exposure, ${ }^{178}$ defendants understandably will be loath to produce that information.

The burden of discovery on the conduct element of a predatory pricing claim renders false positive error highly likely to occur. If a claim makes it past the motion to dismiss stage, defendants are heavily incentivized to settle even nonmeritorious claims, paying money although they are innocent of the conduct alleged. Moreover, those defendants, and others similarly situated, are disincentivized from engaging in vigorous price competition that might later be argued to be predatory in nature, though beneficial to consumers. Iqbal and Twombly counsel for a careful examination of complaints alleging predatory pricing.

\section{b. Unilateral Refusals to Deal}

The question whether a refusal to deal by a monopolist violates $\S 2$ arises in several forms. A monopolist may, for example, refuse to assist a rival. In Aspen Skiing Co. v. Aspen Highlands Skiing Corp.,${ }^{179}$ the Supreme Court faced a claim by a monopolist's rival that a monopolist violated Sherman Act $\S 2$ by refusing to continue a cooperative selling arrangement. Defendant, Aspen Skiing Company, owned three of four ski hills in Aspen, Colorado. Plaintiff, Highlands, owned the fourth hill. Aspen Skiing Company and Highlands had cooperated for years in selling a joint six-day, four-mountain ticket and sharing the revenues generated by the ticket. Aspen Skiing Company terminated the relationship by offering Highlands a revenue split that was unacceptable to Highlands. ${ }^{180}$ Aspen Skiing Company also refused to sell its own daily lift tickets to Highlands, preventing Highlands from creating its own bundled ticket for sale to consumers. ${ }^{181}$

The Court held that Aspen Skiing Company violated $\S 2$ by engaging in such unilateral refusals. The Court reasoned that the refusals injured Highlands, injured consumers, and were not motivated by any legitimate business justifications. ${ }^{182}$ It concluded that Aspen Skiing Company was foregoing revenues in order to injure Highlands. The Court reached that conclusion based on the fact that Aspen Skiing Company had previously been willing to deal with Highlands and ceased doing so for no apparent reason. ${ }^{183}$ Its unilateral refusal to deal was therefore illegal. ${ }^{184}$

178 Such orders may, for example, limit exposure of the sensitive information to plaintiff's counsel and testifying expert.

179472 U.S. 585 (1985).

$180 \mathrm{Id}$. at 592.

181 Id. at 593.

182 Id. at $605-11$.

183 See id. at 608-09.

184 See id. at 610-11. 
A refusal to deal can also take the form of declining to allow access to monopoly infrastructure. In Verizon Communications Inc. v. Law Offices of Curtis V. Trinko, ${ }^{185}$ the Supreme Court addressed another refusal by a monopolist to deal with a rival. In Trinko, the defendant telephone company was required by the Telecommunications Act of $1996^{186}$ to share access to aspects of its local telephone network with its rivals. The plaintiff was a purchaser of telephone services who alleged that the defendant had failed to meet its obligations. The plaintiff alleged that the refusal to share access impeded competition by other telephone companies, much as Aspen Skiing Company's refusal to include Highlands in its bundled ticket deal impeded competition by Highlands. The Trinko Court distinguished Aspen on the ground that the Aspen Skiing Company had refused to sell its tickets to Highland, even though Highlands was willing to pay full retail price. By contrast, the network access that defendant Verizon refused to sell to rivals was not voluntarily for sale in any market at any price. The conclusion, which was warranted in Aspen, that the defendant was foregoing revenues, was unwarranted in Trinko. ${ }^{187}$

Refusals to deal may also be directly aimed at customers or suppliers and have an indirect impact on rivals. In Lorain Journal Co. $v$. United States, ${ }^{188}$ a newspaper refused to sell advertising to local merchants who also advertised on a nearby radio station. ${ }^{189}$ The government argued that this conduct was part of a plan to attempt to monopolize in violation of $\S 2$. The Court upheld an injunction prohibiting the publisher from refusing to accept such advertising. ${ }^{190}$ The Court acknowledged that, in general, sellers may decide with which customers they choose to deal. However, it found that the right to freely select one's customers was not absolute, as "[t]he right claimed by the publisher is neither absolute nor exempt from regulation. Its exercise as a purposeful means of monopolizing interstate commerce is prohibited by the Sherman Act." 191

The conduct element in a unilateral refusal to deal with a rival can thus be understood, after Aspen and Trinko, to require two steps. The

185540 U.S. 398 (2004).

18647 U.S.C. $\$ 271$ (2006).

187 Trinko, 540 U.S. at 409 (“Aspen Skiing is at or near the outer boundary of $\S 2$ liability. The Court there found significance in the defendant's decision to cease participation in a cooperative venture. . . . The refusal to deal alleged in the present case does not fit within the limited exception recognized in Aspen Skiing. The complaint does not allege that Verizon voluntarily engaged in a course of dealing with its rivals or would ever have done so absent statutory compulsion." (citations omitted)).

188342 U.S. 143 (1951).

189 Id. at 148.

190 See id. at $152-53,156$.

191 Id. at 155. 
defendant must refuse to deal with its rival, and must do so against its own economic self-interest. ${ }^{192}$ In an indirect refusal to deal situation like Lorain Journal, the two steps are similar. The defendant must refuse to deal with its customer and must do so with the intent of harming its rival.

Discovery on one step of the conduct element, whether under an Aspen/Trinko theory or a Lorain Journal theory, is simple. The most likely plaintiff is the harmed rival, who is well aware of the facts relevant to the defendant's refusal to deal. If the refusal is indirect, the harmed rival will have access to information about the defendant's refusal from the customer, whether through informal communications outside the judicial process or in discovery-through interviews or deposition. No discovery burden is imposed on the defendant, so no likelihood of false positive error exists.

The second step of the conduct element of a unilateral refusal to deal claim presents a high likelihood of false positive error. Under an Aspen/Trinko direct refusal to deal theory, evidence proving that the refusal to deal is contrary to the defendant's economic self-interest is uniquely in the defendant's control. The burden of discovery is borne exclusively by the defendant, with the attendant concerns for moral hazard. The evidence may also be highly, competitively sensitive, bearing, for example, on the defendant's forward-looking business strategies. For example, one might well imagine the kind of business case-analysis that could accompany a corporate decision to discontinue the historic business practice of selling a multi-mountain lift ticket. Aspen Skiing Company might have been interested only in eliminating a rival. It might also have envisioned undertaking an expansion or a new marketing scheme that would make the multi-mountain ticket inconvenient or unnecessary.

It is also possible that the pertinent evidence on the second part of the conduct element is readily available to the plaintiff, with no threat of discovery burden being imposed on the defendant. One reading of Aspen would permit a claim to be pleaded and proved only on the basis of an unexplained change in the defendant's competitive strategy. It would be sufficient to prove the defendant had previously found it advantageous to deal with the victim-firm and inexplicably ceased doing so. Such circumstantial proof of the defendant's acting against its own economic interest is similar to circumstantial proof of agreement. The evidence of observed marketplace conduct would be as easily available to the plain-

192 Unlike predatory pricing, which is beneficial to consumers in the absence of sustained monopoly pricing producing net consumer harm, there is no initial benefit to consumers through a monopolist's unilateral refusal to deal. Therefore, there is no need for a showing of likely or actual recoupment. 
tiff as it would be to the defendant. ${ }^{193}$ Moreover, because such evidence is public or quasi-public in nature, its disclosure does not implicate the competitive concerns that private information about a defendant's strategic decisions implicates.

In the case of a Lorain Journal-type indirect refusal to deal theory, the second step in the conduct analysis is the defendant's intent to harm its rival. Proof of the defendant's intent often requires access to evidence that is exclusively in the hands of the defendant. Examples include deposition testimony of defendant's executives or documents reflecting the reasons for business decisions. Discovery to find such evidence could be massively burdensome. Where the defendant is a large corporation, determining which of the myriad agents authorized to act on the defendant's behalf held the individual intent to harm the rival might require interviews with, and combing through documents in the possession of, hundreds of employees. ${ }^{194}$ Yet, as with direct refusals to deal, it is also possible to envision evidence of intent to harm a rival being readily available to the plaintiff, and thus, the discovery burden on the defendant being minimal. The information might be quasi-public in nature, if, for example, the defendant announced to its would-be customer that it sought to prevent the success of a nascent competitor.

As with the per se $\S 1$ claim, the likelihood of false positive error turns on whether the conduct in a unilateral refusal to deal claim is to be proved circumstantially or directly. Direct proof implicates burden concerns in a way that circumstantial proof does not. Thus, an allegation of a statement by the defendant (including an agent authorized to act on its behalf) has a higher expected cost of false positive error, and the allegations must be commensurately more specific. An allegation of a lack of a business justification for observed conduct, unsupported by direct evidence, has a lower expected cost, because it relies primarily on expert testimony and publicly available facts. Thus, less specific allegations would be sufficient.

\section{c. Monopoly Leveraging}

Refusals to deal and other strategies may be used by monopolists to affect more than one market. In some situations monopolists are alleged to have leveraged their power in one market in order to gain power in another market. In Eastman Kodak Co. v. Image Technical Services,

193 We do not address here whether, as a matter of substantive law, such purely circumstantial evidence would be sufficient to give rise to liability.

194 This replicates almost precisely the burden concern raised in Twombly. Arguably, the burden of this discovery on a $\$ 2$ claim is less because the chance of criminal prosecution in the modern era is vanishingly small. It is thus less likely that the internal corporate decisionmaking process would be difficult to re-create. 
Inc. ${ }^{195}$ Kodak was alleged to possess a monopoly over repair parts for micrographic machines it manufactured. It was also alleged to have used that power to gain power in repair service for those machines. Kodak refused to sell parts to independent service organizations (ISOs), its rivals in the service market, or to customers who used ISOs for service. ${ }^{196}$ Kodak also entered into agreements with parts manufacturers, who were Kodak's suppliers, that prohibited those manufacturers from selling parts to ISOs. ${ }^{197}$ The Supreme Court held that the plaintiff had presented sufficient evidence to withstand Kodak's motion for summary judgment. 198 The Court viewed the question regarding the conduct element as whether the exclusionary effects of Kodak's policies were justified by legitimate competitive reasons. The Court stated:

The second element of a $\S 2$ claim is the use of monopoly power 'to foreclose competition, to gain a competitive advantage, or to destroy a competitor.' If Kodak adopted its parts and service policies as part of a scheme of willful acquisition or maintenance of monopoly power, it will have violated $\S 2$. . . Liability turns, then, on whether 'valid business reasons' can explain Kodak's actions. ${ }^{199}$

The Court determined that sufficient issues of material fact existed regarding Kodak's asserted justifications to deny summary judgment. ${ }^{200}$

The legitimacy of justifications for conduct that adversely impacts rivals was examined further in a significant case that did not reach the Supreme Court. In United States v. Microsoft Corp. ${ }^{201}$ Microsoft was alleged to have maintained its monopoly in operating systems for personal computers by impeding the development of Netscape Navigator and Java-both forms of "middleware" - that were thought to pose a threat to Microsoft's Windows operating system. The fear was that developers of computer applications programs might ultimately write applications for middleware rather than for Windows. ${ }^{202}$ In assessing whether Microsoft had violated the conduct element of $\S 2$, the court viewed its task as distinguishing actions that are net anticompetitive from those that

195504 U.S. 451 (1992).

196 Id. at 458.

197 Id.

198 Id. at $485-86$.

199 Eastman Kodak Co. v. Image Technical Services, Inc., 504 U.S. 451, 482-83 (1992) (citing Grinnell Corp., 384 U.S. at 570-71; Aspen Skiing Co. v. Aspen Highlands Skiing Corp., 472 U.S. 585, 600-05 (1985); United States v. Griffith, 334 U.S. 100, 107 (1948); United States v. Aluminum Co. of America, 148 F.2d 416, 432 (2d Cir. 1945)).

200 Eastman Kodak, 504 U.S. at 483-86.

201253 F.3d 34 (D.C. Cir. 2001).

$202 I d$. at 53. 
are net pro-competitive. ${ }^{203}$ In undertaking that task, the court applied a methodology similar to the rule of reason applied in $\S 1$ cases. ${ }^{204}$ The court imposed on the plaintiff the burden of demonstrating that the challenged conduct harmed the process of competition rather than merely harming competitors. ${ }^{205}$ The court then shifted the burden to the defendant to come forward with a pro-competitive justification. ${ }^{206}$ It then shifted the burden of rebutting the proffered justification or demonstrating that the anticompetitive harm outweighed the pro-competitive justification back to the plaintiff. ${ }^{207}$ The court acknowledged that it borrowed that methodology from $\S 1$ rule of reason cases. ${ }^{208}$ In evaluating whether the government had met its initial burden of demonstrating that the challenged conduct damaged the competitive process, the court focused on whether the conduct insulated the defendant's product from competition on the merits. ${ }^{209}$

In its most recent $\S 2$ case, the Supreme Court addressed predatory pricing, refusals to deal, and the effects of conduct on more than one market. In Pacific Bell Telephone Co. v. Linkline Communications, Inc., ${ }^{210}$ the defendant, Pacific Bell Telephone, provided high speed internet access ("DSL service") to retail customers. Pursuant to regulatory requirements, it also provided wholesale access to DSL service to other retail providers of that service including the plaintiffs. The plaintiffs alleged that the defendant violated $\S 2$ by charging a high wholesale price to the plaintiffs while charging a low retail price to consumers. The resulting price squeeze allegedly injured competition.

The Court assumed that the defendant had no antitrust duty to deal with the plaintiff. ${ }^{211}$ The Court held that because the defendant had no duty to deal with the plaintiff at all, the terms upon which it did deal

$203 I d$. at 58 ("Whether any particular act of a monopolist is exclusionary, rather than merely a form of vigorous competition, can be difficult to discern: the means of illicit exclusion, like the means of legitimate competition, are myriad. The challenge for an antitrust court lies in stating a general rule for distinguishing between exclusionary acts, which reduce social welfare, and competitive acts, which increase it.").

204 See supra text accompanying notes 145-49.

205253 F.3d at 58-59.

$206 I d$. at 59 ("[I]f a plaintiff successfully establishes a prima facie case under $\S 2$ by demonstrating anticompetitive effect, then the monopolist may proffer a "procompetitive justification" for its conduct. See Eastman Kodak, 504 U.S. at 483. If the monopolist asserts a procompetitive justification - a nonpretextual claim that its conduct is indeed a form of competition on the merits because it involves, for example, greater efficiency or enhanced consumer appeal - then the burden shifts back to the plaintiff to rebut that claim.").

207 Id. ("[I]f the monopolist's procompetitive justification stands unrebutted, then the plaintiff must demonstrate that the anticompetitive harm of the conduct outweighs the procompetitive benefit.").

$208 I d$.

209 Id. at $62,65,75,77$.

210129 S. Ct. 1109 (2009).

211 Id. at 1118 n.2. 
were not subject to challenge under $\S 2 .{ }^{212}$ As to the retail-price portion of the challenged conduct, the Court held that the price would violate $\S 2$ if it met the two-prong test for predatory pricing set forth in Brooke Group. ${ }^{213}$ The Court went on to state that on remand the assessment of any Brooke Group claim would be subject to the pleading standard established in Twombly. ${ }^{214}$

Under the modern analyses demonstrated by Linkline, Microsoft, and Kodak, monopoly leveraging claims, not unlike the predatory pricing and unilateral refusals to deal, turn on the existence or lack of a valid business justification for the observed conduct. As discussed above with regard to refusals to deal under Aspen, proof of a valid business justification sometimes will be possible through expert analysis of public or semi-public information, with little discovery burden imposed on either party. Such circumstantial proof presents a low likelihood of false positive error, because the proof of a business justification is derived primarily from expert testimony based on public information about the market.

But where, as in Linkline, the business justification required is a cost analysis (i.e., that the pricing scheme complained of meets the Brooke Group "appropriate measure of cost" test) the discovery burden is identical to that discussed in subsection $a$ above. The information necessary to demonstrate that the defendant's prices are below cost is uniquely in the defendant's hands, is consequently burdensome to produce, and is enormously, competitively sensitive. The likelihood of false positive error is, therefore, at its highest. ${ }^{215}$

\section{Testing CAses}

Increasing numbers of antitrust courts have been tasked with deciding motions to dismiss since Twombly and Iqbal were decided. This Part considers representative cases in the light of the expected value of falsepositive-error framework we have derived from Twombly and Iqbal. This Part proceeds in the order in which the particular antitrust claims are discussed in Part III.

$212 I d$. at 1119 ("But a firm with no duty to deal in the wholesale market has no obligation to deal under terms and conditions favorable to its competitors. If AT\&T had simply stopped providing DSL transport service to the plaintiffs, it would not have run afoul of the Sherman Act. Under these circumstances, AT\&T was not required to offer this service at the wholesale prices the plaintiffs would have preferred.").

213 Id. at 1120.

$214 I d$. at 1123.

215 See supra notes $176-77$ and accompanying text. 


\section{A. Sherman Act $\$ 1$}

\section{Agreement}

Allegations on the agreement element have been well-tested postTwombly, although fewer cases have been decided post-Iqbal. Because the concern about burdens, which underlies the Twombly rule, is strongest where an agreement will be proved by direct evidence, we would expect courts applying Twombly to hold complaints to a higher bar where proof by direct evidence will be necessary. Conversely, where there are circumstantial allegations, including a sufficient "but-for" allegation tending to exclude the possibility of innocent conduct and proof by circumstantial evidence is a possibility, the complaint should normally be approved.

\section{a. Circumstantial Allegations}

In the years immediately following Twombly, few complaints contained a sufficient but-for allegation. A recent holding by the Second Circuit in Starr v. Sony BMG Music Entertainment is an exception. ${ }^{216}$ Starr dealt with a claim of horizontal agreement on price and non-price terms in the sale of digital music online. The plaintiffs alleged that the defendants charged the same wholesale price for their music and employed identical restrictive contract terms. ${ }^{217}$ The Second Circuit relied on seven "non-conclusory factual allegations of parallel conduct" that it held "plausibly [suggested] that the parallel conduct alleged was the result of an agreement among the defendants." 218 The first was the allegation that the defendants agreed to enter into joint ventures to distribute music. ${ }^{219}$ Second was the allegation that prices stayed high despite decreasing distribution costs. ${ }^{220}$ Third was the parallel maintenance of high prices and restrictive contract terms, even when other distribution channels were employed.221 Fourth and fifth were the use of most-favored nation clauses in licenses with distributors that had the effect of creating price rigidity among the defendants. 222 Sixth was the parallel refusal to deal with one distributor, eMusic, who apparently acted as a maverick in

216592 F.3d 314 (2d Cir. 2010).

217 Id. at $317-19$.

218 Id. at $322-24$.

219 See id. at 318. Although the allegation that the defendants "agreed" is certainly conclusory, see id. at $319 \& \mathrm{n} .2$, the agreement at issue in that allegation was the agreement to form a joint venture, which was conceded, and not the alleged agreement to fix prices. Id.

220 See id. at 318.

221 See id. at 318-19.

222 See id. at 319. 
the distribution marketplace. ${ }^{223}$ Seventh was a parallel price increase among all the defendants. ${ }^{224}$

The court then listed other factors that it believed were consistent with conspiracy being a plausible interpretation of the observed facts. Those included high-concentration contract terms that "one industry commentator noted" were not competitive and a statement by one defendant's CEO stating that one of the joint ventures was meant to "stop the continuing devaluation of music." 225

The Second Circuit's treatment of the circumstantial allegations in Starr suggest that the court believed the plaintiffs were prepared to proceed with proof of agreement without unduly burdensome, or at least not asymmetrically burdensome, discovery proceedings. It noted that the allegations of parallel conduct, with the plus-factor allegations, "taken together, place the parallel conduct 'in a context that raises a suggestion of a preceding agreement, not merely parallel conduct that could just as well be independent action." "226 The Second Circuit's approach is consistent with the framework advanced in this Article. ${ }^{227}$ Because the allegations suggested the plaintiffs were prepared to go forward with proof by circumstantial evidence, the likelihood of false positive error was minimized, and a lighter review at the motion to dismiss stage was warranted. The Second Circuit specifically rejected the argument that it was necessary to identify the specific time, place, or person related to each conspiracy allegation. ${ }^{228}$

The complaint in In re Pressure Sensitive Labelstock Antitrust Litigation $^{229}$ alleged a price-fixing and market allocation agreement. The court in that case had held prior to Twombly that "an agreement among oligopolists to fix prices at a supracompetitive level makes perfect economic sense" based on the alleged market conditions. ${ }^{230}$ Plaintiffs al-

223 See id.

224 See id. at 320 (noting requested leave to amend the complaint to add the parallel price increase allegation).

$225 I d$. at $322-24$.

226 Id. (quoting Bell Atlantic Corp. v. Twombly, 550 U.S. 544, 557 (2007)).

227 This is so although one of us has stated elsewhere that the Second Circuit over-read the importance of the allegations. Comparable to Twombly, the observed facts in Starr are entirely_and perhaps primarily_consistent with interdependent conduct rather than conspiracy. Jacqueline Bell, 2nd Circuit Rule Highlights Twombly Trouble, LAw360 (Feb. 3, 2010) (quoting Max Huffman) (on file with author).

228 See Starr v. Sony BMG Music Entertainment, 592 F.3d 314, 325 (2d Cir. 2010).

229566 F. Supp. 2d 363 (M.D. Pa. 2008).

230 Pressure-Sensitive Labelstock, 566 F. Supp. 2d at 371 (quoting the court's prior opinion, 356 F. Supp. $2 d$ at $493 \&$ n.4). The court may have been wrong in concluding from the allegations that the plaintiffs were prepared to proceed with proof by circumstantial evidence. The fact that it might be in the defendants' economic best interests to collude-an assertion that the Twombly plaintiffs also made-is not sufficient to support a price-fixing claim, and in fact, is nearly tautological. The allegation that that the defendants agreed not to compete for 
leged price leadership by one defendant, despite that defendant's "historical reticence to spearhead price increases." 231 That allegation invoked the one-plus factor the Twombly Court appeared to recognize as sufficient-" complex and historically unprecedented changes in pricing structure."232 With the sufficient but-for allegation, the Pressure-Sensitive Labelstock plaintiffs demonstrated their capacity to proceed to proof by circumstantial evidence, mitigating the discovery burden on the defendant and the attendant likelihood of false positive error.

Insufficient circumstantial allegations demonstrate a plaintiff's reliance on the discovery of direct evidence through burdensome discovery. The Sixth Circuit, in In re Travel Agent Commission Antitrust Litigation, ${ }^{233}$ considered allegations of "a series of uniform base commission cuts adopted by defendant [airlines] over a seven-year period." The plaintiffs alleged that the decisions to match commission cuts initiated by the price leaders in the market were due to an illegal agreement. ${ }^{234}$ The plaintiffs further alleged that the uniform commission cuts "would not have occurred without collusion because such action, if taken independently, was contrary to the individual defendant's economic self interest."235 The Travel Agent Commission plaintiffs did not show their ability to prove their case through circumstantial evidence. Instead, the allegations demonstrate plaintiffs' need to make proof by direct evidence of agreement, as the observed interdependent conduct of the airlines was insufficient to make a circumstantial case of conspiracy. Evidence of actual agreement would be necessary, raising the concern for burdensome and asymmetrical discovery. With the necessity for direct proof,

customers was backed by an industry structure allegation that there was substantial excess industry capacity and that one defendant was idling excess capacity in refusing to compete. $I d$. at 371. On its face, this allegation should fare no better. Any increase in price, whether achieved through innocent, interdependent, and consciously parallel conduct or through illegal conspiracy, would have the effect of idling capacity by comparison to the lower prices. And although plaintiffs alleged that it made no sense economically to idle excess capacity in the absence of an agreement, basic economic theory teaches otherwise. Increasing prices and decreasing output is a common strategy for profit maximization. The fact that prices were at supracompetitive levels both shows the economic rationality of the output restrictions and is itself explainable through innocent, interdependent, and consciously parallel conduct. The court in Pressure-Sensitive Labelstock also found relevant an allegation that one defendant had agreed with a third party not to compete, that the other defendant "was aware of the agreement," and that the other defendant itself forbore from competition. This "suggest[ed] its participation in an overarching conspiracy." Id. at 371 n.7.

231 Id. at 372.

232 Bell Atlantic Corp. v. Twombly, 550 U.S. 544, 557 n.4 (2007); see also In re Graphics Processing Units Antitrust Litig., 540 F. Supp. 2d 1085, 1092-95 (N.D. Cal. 2007) (holding sufficient allegations of changed behavior with regard to product announcements (citing Twombly, 550 U.S. at 557 n.4)); cf. id. at 1096 (direct allegations not always possible and not necessary (citing Oltz v. St. Peter's Hospital, 861 F.2d 1440, 1450-51 (9th Cir. 1988))).

233583 F.3d 896 (6th Cir. 2009).

$234 I d$. at 899.

235 Id. at 900 
the Sixth Circuit required specific allegations of facts that would give notice of plaintiffs' plan for proving the agreement. Simply alleging that an agreement existed was conclusory and insufficient. ${ }^{236}$

In In re Elevators Antitrust Litigation, ${ }^{237}$ the plaintiffs relied exclusively on circumstantial allegations. The Second Circuit held that competitors' use of similar contractual language, product prices, and designs was consistent with competitive business decisions as well as with conspiracy. ${ }^{238}$ The court held that those similarities did not provide "plausible grounds to infer an agreement." 239 Coupling them with "enumerat[ing] basically every type of conspiratorial activity that one could imagine ... in entirely general terms without any specification of any particular activities by any particular defendant" did not help plaintiffs' claims. ${ }^{240}$

The complaint that Elevators held insufficient more robustly alleged plus-factors, tending to increase the opportunities for the defendants to collude, than did the Twombly complaint. The Elevators plaintiffs may have been better prepared than the plaintiffs in Twombly to go ahead with proof of agreement by circumstantial evidence. However, the Elevators

236 Id. at $904-05$.

237 In re Elevators Antitrust Litig., 502 F.3d 47 (2d Cir. 2007).

238 The complaint in Elevators alleged the following conduct: (1) "a combination and conspiracy" Second Consolidated Amended Class Action Complaint Para. 41 In re Elevators Antitrust Litig., 502 F.3d 47 (2d Cir. 2007) (Nos. 04-CV-01178(TPG)), 2005 WL 3736019, (2) "a continuing agreement, understanding and concert of action among the defendants and coconspirators," id. Para. 42, (3) "meetings and conversations in Europe and the United States to discuss the prices . . and to discuss the applicable customers or markets," id. Para. 43(a), (4) that the defendants "[a]greed, during those meetings and conversations, to charge prices at certain levels and otherwise increase or maintain prices," $i d$. Para. 43(b), (5) that the defendants "[a]greed in advance on bid prices and bid winners," id. Para. 43(c), (6) that the defendants "[a]llocated markets and customers . . . consistent with the agreements reached," id. Para. 43(e), and (7) that the defendants "[a]greed and took collective actions to drive independent . . . companies out of the marketplace," $i d$. Para. 43(g).

The complaint also alleged facts that increased the opportunity to successfully collude, including: (1) "[t]he industry . . . is characterized by economic conditions that are consistent with and conducive to the conspiracy," id. Para. 45, (2) "[t]here are a relatively small number of companies ... and high barriers to entry," id. Para. 45, (3) "[t]he industry . . . is highly concentrated," id. Para. 46, (4) "[t]he market . . . is an oligopoly," id. Para. 47, (5) "[t]he industry . . is closely knit, with many of a Defendants' management personnel having family or close friends who are employed by another Defendant," $i d$. Para. 47, (6) "[c]ompany executives ... often attend industry, trade association and social functions together," id. Para. 47, (7) "[e]ach Defendant belongs to a number of associations and trade groups," id. Para. 48, and (8) the existence of "standard industry practices," $i d$. Para. 49.

The complaint included an attempt at a but-for allegation. "There is no objective or procompetitive justification for any of this conduct." Id. Para. 58.

Finally, the complaint listed conclusory allegations of violations of Sections One and Two, engaged in collectively by the defendants and, in the case of some $\S 2$ claims, individually by certain defendants. Id. Para. 76-133.

239 Elevators, 502 F.3d at 50, 51 (quoting Bell Atlantic Corp. v. Twombly, 550 U.S. 544, 556 (2007)).

$240 I d$. at 50 (quoting the district court opinion). 
complaint contained only a weak attempt at a "but for" allegation, alleging only that there was "no objective or pro-competitive justification" for the observed conduct. ${ }^{241}$ No allegation in the Elevators complaint took the essential step required of circumstantial allegations by Twombly of tending to exclude the possibility of unilateral conduct. ${ }^{242}$ Just as in Twombly, then, the Elevators plaintiffs' failure to sufficiently plead circumstantial evidence implicated the necessity of proving their claim through direct evidence, which raised the plausibility bar.

241 Second Consolidated Amended Class Action Complaint Para. 58 In re Elevators Antitrust Litig., 502 F.3d 47 (2d Cir. 2007) (Nos. 04-CV-01178(TPG)), 2005 WL 3736019.

242 Elevators thus should be read as interpreting Twombly to limit sufficient plus-factor allegations to those that tend to exclude the possibility of unilateral conduct. This interpretation of the plus factor framework was argued to the Supreme Court in Twombly, see Brief for Legal Scholars as Amici Curiae in Support of Petitioners at 25-26, Bell Atlantic Corp. v. Twombly, 550 U.S. 544 (2007) (No. 05-1126), 2006 WL 2474080, and is the best explanation for the Second Circuit's holding in Elevators that even substantial plus-factor allegations were insufficient to survive a Twombly motion. The Ninth Circuit, reviewing an order of dismissal in Kendall v. Visa USA, Inc., likewise rejected allegations of parallel conduct coupled with the allegation that the defendants "knowingly, intentionally and actively participated in an individual capacity in the alleged scheme' to fix [prices]." 518 F.3d 1042, 1048 (9th Cir. 2008) (citing Complaint II 11); see also Native Am. Distrib. v. Seneca-Cayuga Tobacco Corp., 546 F.3d 1288, 1297-98 (10th Cir. 2008) (holding conclusory allegations of conspiracy without supporting factual allegations insufficient); Shames v. Hertz Corp., 2008 WL 4103985 (S.D. Cal. Jul. 24, 2008) (dismissing price fixing complaint); Windage, LLC v. U.S. Golf Ass'n, 2008 WL 2622965 (D. Minn. Jul. 02, 2008) (conspiracy element of a group boycott claim); In re Parcel Tanker Shipping Servs. Antitrust Litig., 541 F. Supp. 2d 487 (D. Conn. 2008) (dismissing price fixing complaint); Southeast Missouri Hosp. v. C.R. Bard Inc., 2008 WL 199567 (E.D. Mo. Jan. 22, 2008) (dismissing conspiracy allegations for failure to allege anything beyond parallel conduct); Int'l Norcent Tech. v. Koninklijke Philips Elecs. N.V., 2007 WL 4976364, at $* 10$ (C.D. Cal. Oct. 29, 2007) (dismissing complaint alleging a standard-setting agreement partly on the basis of a failure sufficiently to allege the defendants reached agreement); Sheridan v. Marathon Petroleum Co., 2007 WL 2900556 (S.D. Ind. Sept. 28, 2007) (dismissing complaint alleging tying and price-fixing agreements); Schafer v. State Farm Fire \& Cas. Co., 507 F. Supp. 2d 587, 596-97 (E.D. La. Aug. 22, 2007) (dismissing price fixing allegations on the basis of failure to allege more than interdependent conduct). Kendall was an easy case, as the complaint contained nothing but a bare allegation of conspiracy, which Twombly - consistent with the great weight of prior authority-had held insufficient. See DM Research, Inc. v. College of Am. Pathologists, 170 F.3d 53, 56 (1st Cir. 1999) ("[T]erms like 'conspiracy,' or even 'agreement,' are border-line: they might well be sufficient in conjunction with a more specific allegation-for example, identifying a written agreement or even a basis for inferring a tacit agreement - but a court is not required to accept such terms as a sufficient basis for a complaint. The case law on this point is ample." (citations omitted)). No facts alleged constituted plus factors, and certainly no facts alleged in Kendall tended to exclude the possibility of unilateral conduct. The Kendall plaintiffs apparently hoped to rely on direct proof of conspiracy, which implicates the more burdensome sort of discovery and favors a searching review of complaints. See, e.g., Rik-Mik Enters. v. Equilon Enters., Inc., 532 F.3d 963, 975-76 (9th Cir. 2008) ("The nature of the conspiracy or agreement is not alleged. The type of agreements are not alleged."). 


\section{b. Direct Allegations}

Starr and Pressure-Sensitive Labelstock are rare cases involving complaints that survive on the basis of sufficient circumstantial allegations. Most complaints that survive rely on direct allegations of agreement that are sufficiently specific to mitigate the concern for burden. ${ }^{243}$ Pressure-Sensitive Labelstock also contained direct allegations that might meet the Twombly/Iqbal standard. The plaintiffs in that case alleged "direct discussions about the need to collaborate on price increases during the October 2000 conference" of the industry trade association. ${ }^{244}$ Such a specific allegation permits the trial court to carefully cabin the discovery required to produce evidence relating to that allegation. The district court could limit discovery to those agents of defendants present at the October 2000 conference and could limit it to topics related to that conference. Because of the specificity of the direct allegations, the burden concern is minimized.

Allegations of a rebate ban imposed by a trade organization on its members were sufficient direct allegations of a conspiracy in Hyland $v$. Homeservices of America, Inc. ${ }^{245}$ The complaint "alleged admissions of price-fixing by real estate brokers [and] an exchange of price information and catalogues between the parties." 246 The plaintiffs in Hyland also alleged the rebate ban, which had been the subject of a civil action by the U.S. Department of Justice. ${ }^{247}$ Because the complaint alleged a conspiracy directly, rather than circumstantially, burdensome discovery was threatened in Hyland. However, the allegations were sufficiently detailed to offer the court a path to cabining discovery. The plaintiffs might be permitted to inquire into the statements supposedly constituting

243 See In re Static Random Access Memory Antitrust Litig., 2008 WL 426522, at*3 (N.D. Cal. Feb. 14, 2008) (plaintiffs argued they had made direct allegations of agreement); Schafer v. State Farm Fire \& Cas. Co., 507 F. Supp. 2d 587, 596 n.26 (E.D. La. 2007) (citing Janet L. McDavid \& Eric Stock, Bell Atlantic v. Twombly, 29 NAT'L L.J. 47 (2007)). See generally William H. Page, Twombly and Communication, supra note 131, at 455-64 (citing authorities for the proposition that pleading agreement under $\S 1$ requires pleading communication between the parties).

244 In re Pressure Sensitive Labelstock Antitrust Litigation, 566 F. Supp. 2d 363, 372 (M.D. Pa. 2008); see also In re TFT-LCD (Flat Panel) Antitrust Litig., 586 F.Supp.2d 1109, 1115-17 (N.D. Cal. 2008) (alleging, among other things, "specific instances of invitations to agree and subsequent agreements," "statements by [one defendant] boasting that it had succeeded in convincing its competitors to cut capacity," and the "exchange [of] numerous types of sensitive competitive information"); In re Static Random Access Memory (SRAM) Antitrust Litig., 580 F. Supp. 2d 896, 901-04 (N.D. Cal. 2008) (detailing allegations of communications between defendants and concluding the facts were sufficient to meet Twombly's standard for circumstantial conspiracy allegations).

2452007 WL 2407233 (W.D. Ky. Aug. 17, 2007).

$246 I d$. at $* 3$.

247 Third Amended Class Action Complaint paras. 50-58 (No. 3:05-CV-612-R), Hyland v. Homeservices of Am., 2007 WL 2407233 (W.D. Ky. Aug. 17, 2007), 2007 WL 2933237. 
admissions, the exchange of price information, and the rebate ban, but no further.

Direct allegations of "swap" agreements between cable service providers in different geographic locales were sufficient to state a $\S 1$ claim in Behrend v. Comcast Corp. ${ }^{248}$ The agreements involved trading customers in such a way that the defendants gained greater market power in their respective locations. The complaints included direct allegations of agreements. ${ }^{249}$ The Behrend Court stated that "[t]he [complaints] provide factual descriptions of the parties, their roles as competitors in the geographic markets, when the agreements were completed, and how the terms thereof allegedly eliminated competitors in, and raised entry and reentry barriers to, the [markets]." 250 Although direct allegations raise greater burden concerns, the allegations in Behrend were easily specific enough to overcome the concern for burden associated with one-sided discovery.

There were both direct and circumstantial allegations in City of Moundridge v. Exxon Mobil Corp., ${ }^{251}$ which involved allegations of price fixing by natural gas refiners in a suit by plaintiff municipalities. The court in that case considered circumstantial allegations of price fixing: "the natural gas total resource base had not decreased, . . . the prices had risen and never fallen below an agreed-upon price, . . . the defendants had reported high profits, and . . . Hurricanes Katrina and Rita should not have affected the market as the defendants claimed." 252 Providing "historical supply and consumption levels, market prices, profit levels, and the use of industry reports," was sufficient "to support an

248532 F. Supp. $2 d 735$ (E.D. Pa. 2007). The Behrend complaint alleged violations of both Sections One and Two by Comcast Corporation and its affiliates. Third Amended Class Action Complaint for Violations of the Sherman Antitrust Act paras. 3, 6, 9 (No. 03-6604), Behrend v. Comcast Corp., 532 F. Supp. 2d 735 (E.D. Pa. 2007), 2006 WL 1760198. The theories of harm are reminiscent of those advanced in Twombly. The $\S 1$ theory is one of market division - creating customer clusters to avoid competition within markets. Id. at para. 10. The Section Two theory, also like Twombly, is that the defendant refused to allow access to its facilities to would-be new entrant competitors. Id. at para. 11. Unlike in Twombly, however, in Behrend, the plaintiffs were able to allege several specific agreements that they believed constituted market allocations. Id. at paras. 54-56. The $\S 2$ allegations, likewise, included a litany of alleged mergers through which the defendants gained market share in the alleged markets. $I d$. at paras. 51-53. Both of the theories are suspect as a matter of substantive law, but unlike Twombly, the Behrend complaint did not turn on conclusory legal assertions.

249 Behrend, 532 F. Supp. 2d at 741.

250 Id.; see also Omnicare, Inc. v. Unitedhealth, Inc., 524 F. Supp. 2d 1031, 1038 (N.D. Ill. 2007) (direct allegations of a merger agreement sufficient to allege an agreement to coordinate decisions pre-merger). Omnicare is a surprising result. The court held that there were direct allegations of an agreement, although the terms of the agreement-to merge-were not the basis for the antitrust claim, which was pre-merger coordination. Id.

251250 F.R.D. 1 (D.D.C. 2008).

252 Id. (citing the Second Supplemental Complaint IIII 36, 37). 
inference that the defendants engaged in not merely parallel conduct, but rather agreed" to fix prices. ${ }^{253}$ There were also some direct allegations: the complaint also identified "the years and locations where the agreement was reached and the defendants who participated."254

City of Moundridge is another case in which the circumstantial allegations were insufficient to obviate the need to rely on proof by direct evidence. ${ }^{255}$ The allegations that profits were high, that supply was restricted despite ample resources, and that those phenomena could not be explained by external forces such as hurricanes do not exclude the possibility of oligopoly pricing through interdependent conduct. Therefore, they should not be sufficient "but for" allegations to permit plaintiffs to proceed on proof by circumstantial evidence. However, the complaint provided sufficiently specific allegations with regard to the conduct from which an agreement could be inferred to permit the plaintiffs to proceed on a theory of proof by direct evidence. ${ }^{256}$

Courts are still feeling their way in applying the Twombly/Iqbal standard to conspiracy allegations. The primary difficulty appears to be a lack of appreciation of the underlying rationale for the standard. The

253 Id.

254 Id. (citing the Second Supplemental Complaint III 15, 17-18).

255 See also Hackman v. Dickerson Realtors, Inc., 557 F. Supp. 2d 938 (N.D. Ill. 2008). Hackman held that allegations against one defendant that she knew of a group animus, which later (in her absence) led to a conspiracy, and that she acted consistently with it, were sufficient to permit discovery as to whether she was actually a member of the conspiracy. Id. at 944. The allegations against the defendant were that she took actions consistent with the alleged group boycott, that she "knew of the vendetta against" plaintiff, and that she had previously worked for the area realtor's association. Id. (citing Amended Complaint II 43). The court acknowledged that the sufficiency of those allegations "is a closer call." Id. at 944. Allegations against other defendants in Hackman, which include the allegation that at a specified meeting, "the agency Defendants . . . agreed not to do business with" plaintiff, id. (citing Amended Complaint II 36), are sufficient under Twombly. The amended Hackman complaint did not include a direct allegation that the defendant communicated her involvement to the other alleged co-conspirators. The Hackman court may have over-read the allegations. The circumstantial allegations in Hackman with regard to the one defendant were neutral as to whether she was a party to an agreement. She could have known of the group animus against the plaintiff without knowing of the alleged conspiracy. Even if she knew of the agreement, she might nonetheless have unilateral incentives to act in a manner consistent with it. For example, a maverick firm may decline to join a price fixing conspiracy but take advantage of the price umbrella created by the minimum price fixing and unilaterally raise its own prices. Cf. Cosmetic Gallery, Inc. v. Schoeneman Corp., 495 F.3d 46, 53-54 (3d Cir. 2007) (holding, at the summary judgment stage, that without evidence that conduct was contrary to a defendant's unilateral self interest, a conspiracy was not demonstrated by circumstantial evidence). The allegations in Hackman also lack sufficient specificity to allow plaintiffs to prove agreement by direct evidence. The danger of burdensome, one-sided discovery existed in Hackman.

256 City of Moundridge, 250 F.R.D. at 5 \& n.4 (circumstantial allegations plus specific direct allegations are sufficient to survive a motion to dismiss (citing In re OSB Antitrust Litig., 2007 WL 2253419, at *5 (E.D. Pa. Aug. 3, 2007))); see also Fair Isaac Corp. v. Equifax Inc., 2008 WL 623120, at*5-*6 (D. Minn. Mar. 4, 2008) (holding circumstantial allegations of agreement were sufficient where the temporal period in which the alleged agreement was hatched was minimized). 
rationales advanced here explain the appropriate treatment of circumstantial and direct allegations. Where the allegations demonstrate a capacity to proceed with circumstantial proof, as in Starr and Pressure-Sensitive Labelstock, the expected cost of false positive error is relatively low, and discovery should be permitted to proceed. Where allegations demonstrate a need to proceed with direct evidence, the expected cost of false positive error is high. Only where the allegations are sufficiently detailed, so as to cabin the discovery requests, should the complaint survive-as in cases like Hyland and Behrend. But, in cases like Travel Agent Commissions and Elevators, insufficient circumstantial allegations coupled with no, or insufficient, direct allegations necessitate dismissal.

\section{Reasonableness}

The Ninth Circuit applied Twombly to a rule of reason claim in William O. Gilley Enterprises v. Altantic Richfield Co. ${ }^{257}$ In Gilley, the agreement element was alleged via claims of "exchange agreements"express contracts-between defendant oil producers. ${ }^{258}$ Given the nature of the claims, the question involved the sufficiency of pleading the effects of those contracts. The court stated that "[b]ecause each of the exchange agreements arguably affects only a small amount of CARB gas, [p]laintiffs pleaded the cumulative effect of a single Defendant's exchange agreements to show market power and anticompetitive effect." 259 The majority held that aggregation of the effects of many discrete agreements is legally permissible. ${ }^{260}$

257561 F.3d 1004 (9th Cir. 2009), vacated on other grounds, 588 F.3d 659 (2009). A lower court in the Ninth Circuit has also done so, in that case reaching an erroneous conclusion. See Int'l Norcent Tech. v. Koninklijke Philips Elecs. N.V., 2007 WL 4976364 (C.D. Cal. Oct. 29, 2007). In International Norcent Technology, the agreement alleged was a standardsetting agreement relating to a video-disc technology. Id. at *8-*9. Because such standardsetting is subject to the rule of reason, litigation over the impact of the agreement produces low and symmetrical discovery burdens. See supra notes 150-51 and accompanying text. Dismissal should not be appropriate for failure sufficiently to allege the competitive harm from such an agreement. The court's error in International Norcent Technology appears to be uncritically importing lessons from the process of pleading agreement into other elements of the Section One claim. See id. at *8.

258 Id. at 1010. Gilley is an example of the reality, which we discussed above, that where the alleged violation is something other than hard-core cartel conduct, it will usually be the case that the behavior is not hidden. It therefore does not present a pleading problem regarding the agreement element. See also Starr v. Sony BMG Music Entertainment, 592 F.3d 314, 326-28 (2d Cir. 2010) (concession that joint venture agreement existed precluded dismissal of conspiracy claims); In re Hypodermic Products Antitrust Litig., 2007 WL 1959224, at *14-*15 (D.N.J. June 27, 2007) (holding direct allegations of agreement sufficient to state a claim; allegations of anticompetitive effects could not be evaluated at the motion to dismiss stage).

259561 F.3d at 1010 .

260 See id. 
Over defendants' arguments that the exchange agreements were efficiency-enhancing, the court held the factual question of the anticompetitive effects of the aggregated contracts, balanced against the procompetitive efficiencies they offered, could not be resolved at the motion to dismiss stage. ${ }^{261}$ Given the low and symmetrical burden of discovery on the reasonableness element, the Gilley court correctly applied the pleading standard defined by Iqbal and Twombly.

\section{B. Sherman Act § 2}

\section{Predatory Pricing}

While decided on the basis of antitrust injury, the Sixth Circuit's en banc decision in NicSand, Inc. v. $3 M$ Company, 262 can be instructively analyzed as a $\S 2$ decision. ${ }^{263}$ The Sixth Circuit held that the plaintiff would lack standing if the conduct it complained of was not illegal under $\S 2$. It then proceeded to consider the plaintiff's allegations in the light of the substantive standard for $\S 2$ liability. ${ }^{264}$

261 Id. at 1011. Contra Lady Deborah's, Inc. v. VT Griffin Servs., Inc., 2007 WL 4468672 , at $* 8$ (S.D. Ga. Oct. 26, 2007) (dismissing on the basis of the defendant's failure to allege injury to competition). The Gilley dissent recognized that "Twombly involved an alleged conspiracy based on parallel conduct and this case is ostensibly not a conspiracy case." Gilley, 561 F.3d at 1019 (Callahan, J., dissenting). But the dissent read the complaint as being ambiguous as to what the agreements actually were, contending that rather than relying on each defendant's aggregated, bilateral exchange agreements, the plaintiffs were in reality hoping to establish a conspiracy represented by a web of bilateral agreements among the defendants. Under that understanding, the plaintiffs' allegations fell short of adequately identifying the agreements. Id. at 1021 .

262507 F.3d 442 (2007) (en banc).

263 Nicsand applied the Twombly standard to the antitrust injury element of antitrust standing, which requires that the plaintiff allege harm from the anticompetitive impacts of an antitrust violation. Id. at 451 (quoting Bell Atlantic Corp. v. Twombly, 550 U.S. 544, 556-58 (2007)); see also CBC Companies v. Equifax, Inc., 561 F.3d 569, 571-72 (6th Cir. 2009) (same); Int'l Norcent Tech. v. Konenklijke Philips Elecs. N.V., 2007 WL 4976364, at*15 (C.D. Cal. Oct. 29, 2007) (failure sufficiently to allege antitrust injury is an alternative basis for dismissing the complaint). Other courts have also applied Twombly to the antitrust standing requirement, the most prominent factor of which is the requirement of antitrust injury. The court in Hypodermic Products held that an allegation that "by unlawfully excluding and impairing competition, [defendant]'s conduct has caused Plaintiffs and the other Class members to pay more . . . than they otherwise would have paid" sufficiently alleged antitrust injury. 2007 WL 1959224, at *10 (quoting Amended Complaint II 107); see also id. at*15. Antitrust injury requires a showing that the plaintiff was harmed by reason of a violation of the antitrust laws. See Max Huffman, A Standing Framework for Private Extraterritorial Antitrust Enforcement, 60 SMU L. REv. 103, 108 \& n.29 (2007). That showing therefore necessitates a showing of an antitrust violation. Some courts, like NicSand, have treated the antitrust injury question as a preliminary analysis of the substantive antitrust claim. See Joseph P. Bauer, The Stealth Assault on Antitrust Enforcement: Raising the Barriers for Antitrust Injury and Standing, 62 U. PIтT. L. Rev. 437, 448-49 (2001) (noting in one case that a conclusion pertaining to the lack of antitrust injury reflected "uncertainty about the merits of the claim").

264 NicSand, 507 F.3d at 451. 
NicSand showcases the difficulties facing a $\S 2$ plaintiff pleading a claim after Twombly. The NicSand plaintiffs alleged that 3M had made cash payments, which were "nothing more than 'price reductions offered to the buyers" "to retailers in order to earn their business. ${ }^{265}$ The majority held the plaintiffs had conceded in their briefing the prices charged were not predatory. ${ }^{266}$ The dissent disagreed that such a concession had been made. It compared the size of the up-front payments by $3 \mathrm{M}$ with the profits plaintiffs had earned in the market in a recent year. That comparison indicated that plaintiff would suffer a loss in many transactions if it made such a large up-front payment. ${ }^{267}$ The dissent argued that the analysis created a sufficient inference that $3 \mathrm{M}$ was earning a loss in those transactions-thus, pricing below-cost and implicating $\$ 2268$ - that plaintiff should be entitled to discovery. ${ }^{269}$ The burden of discovery on the below-cost aspect of the predatory pricing claim makes it appropriate under Iqbal and Twombly to subject the complaint to a searching inquiry, in order to avert the false positive concern that ranks so high on those claims. But it seems likely the dissent has the better argument in NicSand. It is not clear that a predatory pricing plaintiff can do better than to posit its own costs as a plausible proxy for the defendant's costs and to compare that proxy to publicly available information about the defendant's prices. The plaintiff did so, and the complaint should have survived the motion to dismiss.

\section{Monopoly Leveraging}

In one of the few explicit applications of Twombly to a $\S 2$ claim, the district court in In re Hypodermic Products Antitrust Litigation, ${ }^{270}$ applied the Twombly standard in denying a motion to dismiss a complaint alleging violations of both $\S \S 1$ and $2 .{ }^{271}$ The court required that

265 Id. at 452.

266 Id. Contra NicSand, 507 F.3d at 463 (the majority's assertion that plaintiff conceded this point is "misleading").

267 NicSand, 507 F.3d at 462 (Martin, J., dissenting).

268 See infra notes 166-77 and accompanying text (describing standards for predatory pricing).

269 NicSand, 507 F.3d at 462-63 (Martin, J., dissenting). Another of plaintiff's claims against $3 \mathrm{M}$ in NicSand-that 3M engaged in exclusive dealing with retailers through multiyear agreements, foreclosing plaintiff from the market-does not present the same problem under Twombly because no inference is necessary. The plaintiff was able to allege the existence of an agreement, thus permitting the court to evaluate the alleged agreements on the merits. The Sixth Circuit concluded that the agreements were not anticompetitive. NicSand, 507 F.3d at 453-54. The dissent did not argue, as it did with regard to predatory pricing, that the court was required to indulge an inference with regard to a fact that was unknowable without discovery. The allegations were direct, but the conduct alleged was held not to be a $\S 2$ violation.

270 In re Hypodermic Prods. Antitrust Litig., 2007 WL 1959224 (D.N.J. June 29, 2007).

271 Hypodermic Products also applied the Twombly standard to the antecedent question of whether the plaintiffs had antitrust standing. 2007 WL 1959224, at *6-*7. The allegations of 
the complaint allege the two elements of a $\S 2$ violation, "that [defendant] possesses monopoly power" and "that [defendant] has maintained such a monopoly by unlawful means." 272

The court held that the first element had been sufficiently alleged by the claim that the "[d]efendant illegally acquired and maintained monopoly power over various hypodermic products and markets for those products," together with allegations of how those markets were defined. ${ }^{273}$ Because the market-power element of $\S 2$ creates relatively little danger of false positive error, ${ }^{274}$ and the allegations provide sufficient specificity to overcome what discovery burden concerns do exist, the conclusion that the Hypodermic Products complaint sufficiently alleged market power $^{275}$ is correct.

In Hypodermic Products, the plaintiff sufficiently pleaded the conduct element of monopolization. The successful allegations included claims that: (1) "Defendant . . . has used . . . various anti-competitive and illegal practices to achieve and maintain its dominant market position" against "superior products . . . or cheaper products," and (2) defendant "impos[ed] market share purchase requirements," (3) "bundl[ed] its goods for exclusionary purposes," (4) "conspir[ed] with [Group Purchasing Organizations]" for the purpose of imposing exclusionary contracts,"

harm suffered from the antitrust violation, a requirement of standing under Brunswick Corp. $v$. Pueblo Bowl-O-Mat, 429 U.S. 477 (1977), was sufficiently pleaded when plaintiff alleged facts creating an inference of harm that was inextricably intertwined with harm in the relevant product markets. Id. at $* 9$.

2722007 WL 1959224, at *10 (applying the elements of a monopolization claim under $\S 2$ from United States v. Dentsply, 399 F.3d 181, 186 (3d Cir. 2005): “(1) possession of monopoly power in the relevant product market and (2) ' . . . maintenance of that power as distinguished from growth or development as a consequence of a superior product, business acumen, or historic accident'").

273 Hypodermic Prods., 2007 WL 1959224, at *10, *12 ("The Court . . has been given no reason to believe that the relevant markets, as plead in the Complaint, are anything but plausible." (quoting Amended Complaint II 3)). But see Little Rock Cardiology Clinic v. Baptist Health, 573 F. Supp. 2d 1125, 1139-50 (E.D. Ark. 2008) (applying Twombly to allegations about the relevant market both for a $\S 1$ and a $\S 2$ rule of reason claim, holding that the plaintiff had failed to plead the relevant market properly, even though the plaintiffs' failings were not due to a lack of information about the product market, which might have been alleviated by further discovery. Instead, the markets alleged simply were legally insufficient); see also Rik-Mik Enters. v. Equilon Enters., Inc., 532 F.3d 963, 972-73 (9th Cir. 2008) (failure to allege market power in the tying market for purposes of a $\$ 1$ claim); Lady Deborah's, Inc. v. VT Griffin Servs., Inc., 2007 WL 4468672, at *10 (S.D. Ga. Oct. 26, 2007) (holding failure to allege facts showing defendant's power over price defeated a $§ 2$ claim).

274 See supra notes 161-62 and accompanying text.

275 The Hypodermic Prods. court found no need to discuss other allegations related to the market definition element of the monopolization claim. The plaintiffs had also alleged that "there is no product that can reasonably be substituted for" four of the different products, Amended Complaint paras. 29, 34, 39, 44 and 46, In re Hypodermic Products Antitrust Litig., 2007 WL 1959224 (D.N.J. June 29, 2007) (05-CV-1602 (JLL/CCC)), 2006 WL 2430091, and that the "defendant has . . . a market share in excess of $70 \%$ " With respect to three of the different products. Id. paras. $31,36,41$. 
and (5) "conspir[ed] with other manufacturers to 'impose rebate penalties on purchasers relating to a bundle of products.' "276 In addition to the general allegations of anticompetitive conduct, the complaint included specific allegations of vertical agreements between the defendant and purchasers, which had the effect of preserving defendant's high-market share. ${ }^{277}$ Comparing those allegations to those the Supreme Court held insufficient in Twombly, the Hypodermic Products court noted that the conspiracy alleged in Twombly was based on inference from observed innocent conduct, while the conduct alleged in Hypodermic Products was "specific anti-competitive agreements." 278

The Hypodermic Products plaintiffs were able to allege the conduct directly. 279 The court noted "such allegations . . . [were] in sharp contrast with the allegations found to be insufficient in [Twombly]." 280 The Twombly complaint "sought to demonstrate anti-competitive agreements based on parallel conduct through inference. To the contrary, the instant Complaint sets forth allegations of specific anti-competitive agreements ...."281 The varieties of conduct meeting the second element of a monopolization claim makes it difficult to generalize about applying the Twombly/Iqbal framework to monopolization cases. But, as with antitrust claims generally, when a monopolization claim requires proof by reference to a defendant's internal documents and information, the threatened discovery burden will counsel for careful review of the complaint's allegations. When proof may be made with public or semi-public information (such as market analysis or customer testimony) the reduced discovery burden counsels for permissive treatment of the complaint.

\section{Summary}

Germs of the framework we outline can be found in case law decided since Twombly and Iqbal. Section One cases turning on the agreement element are not surprisingly the best represented in the small sample of antitrust cases that analyze the Supreme Court's recent pleading authorities in depth. Within that category, the divide between the Second Circuit's opinion in Starr and the Sixth Circuit's opinion in In re Travel Agent Commissions exemplifies the important dichotomy between proof by circumstantial evidence and proof by direct evidence. A suffi-

276 Hypodermic Prods., 2007 WL 1959224, at *10 (quoting Amended Complaint IIII 6, 7).

277 Id. at $* 13$.

278 Id. at $* 14$.

279 Cf. William O. Gilley Enterprises v. Atlantic Richfield Co., 561 F.3d 1004 (9th Cir. 2009).

280 Hypodermic Products, 2007 WL 1959224, at *14.

281 Id.; see also In re Hypodermic Prods. Antitrust Litig., 2007 WL 1959225, at*12 (D.N.J. June 29, 2007). 
ciently robust showing of circumstantial allegations should give a court reviewing the complaint confidence that the plaintiff is prepared to proceed without unduly burdening the defendant during discovery, thus mitigating the likelihood (and the expected cost) of false positive error. However, a skeletal showing of observed conduct, or a showing of conduct that produces an inference of unilateral activity, shows that proof by direct evidence will be necessary. The consequent burden on the defendant during discovery counsels for dismissal. The third category of agreement cases, represented by Behrend v. Comcast Corp., are those in which plaintiffs are able to plead specific direct allegations of agreement. Such allegations demonstrate the likely merit of the plaintiffs' claims and impact the expected cost analysis by reducing the likely cost because discovery will not be a fishing expedition.

The relatively low discovery burden on the reasonableness element of a $\S 1$ claim suggests courts should rarely dismiss when proof will turn on that element. The Gilley Court, in holding that discovery was necessary to determine the effects of agreements (the existence of which was not contested), is consistent with that approach.

We demonstrated in Part III that monopolization claims under $\S 2$ are proved with facts showing monopoly power and facts showing conduct. The former present little concern for false positive error due to burdensome discovery because they are proved circumstantially. In re Hypodermic Products had little trouble concluding that element was sufficiently alleged. The facts required to prove conduct, however, are more varied (in part because of the variety of conduct meeting that element of the monopolization claim). Predatory pricing claims, for example, require a burdensome inquiry into the defendant's cost structure. The Sixth Circuit in NicSand v. 3M concluded that the allegations in the complaint were insufficient to allow discovery on that element. Monopoly leveraging presents a more context-specific problem. Proof of the "no business justification" showing from Aspen can be made directly or circumstantially. As with the agreement element of a $\S 1$ claim, direct proof raises concerns for burdensome discovery into the defendant's business plans, while circumstantial proof involves a nonburdensome market analysis. In re Hypodermic Products allowed discovery to proceed on a theory that was to be proved directly because the complaint was sufficiently specific to mitigate the burden on the defendant.

As we conclude below, that same analysis of the facts required to prove a claim may be developed for any antitrust claim or any claim that may be the subject of private federal litigation. 


\section{Conclusion}

In Twombly and Iqbal the Supreme Court was faced with the question of when a plaintiff should be allowed to proceed with discovery. Procedurally, that question arises when a court is asked to dismiss a plaintiff's complaint. Granting a motion to dismiss creates the risk of false negative error, because the complaint may assert a claim that discovery and trial would reveal to be meritorious. Denying a motion to dismiss, however, creates the risk of false positive error since the prospect of burdensome discovery may cause a defendant to settle a case that discovery and trial would reveal to be nonmeritorious. In Twombly and Iqbal, the Supreme Court chose to focus on the risk of false positives, imposing a stringent pleading requirement on plaintiffs whose complaints raised the prospect of burdensome discovery.

Both Twombly and Iqbal involved areas of substantive law in which the cost of false positive errors is high, and both involved situations in which the likelihood of false positive error was high. The likelihood of false positives was high because the cases focused on elements of claims that raise the prospect of disproportionately burdensome discovery on the defendant. This was so because the facts relevant to those elements were known directly by the defendants principally. Because the expected cost of false positive error was high, the Court imposed a stringent pleading standard on both sets of plaintiffs.

The rationale behind Twombly and Iqbal's pleading standards thus applies where both the cost and the likelihood of false positives are high. If the expected cost is not high, the stringent pleading standard applied in Twombly and Iqbal is not justified. Applying the Twombly/Iqbal reasoning, therefore, requires an assessment of the expected cost implicated by each element of each substantive claim in controversy. Part III demonstrated the application of that reasoning in the context of various elements of claims under $\S \S 1$ and 2 of the Sherman Act, and concluded that the expected cost of false positive error was high only with respect to some of those elements. Thus, the stringent pleading standard applied in Twombly and Iqbal would be justified in application only to those elements of Sherman Act claims. Determining the correct approach to pleading in other substantive areas of law will require similar elementby-element analysis. 